\title{
Research Paper \\ The Effectiveness of Parent based Metacognitive Executive Functions Training on Behavioral Symptoms and Cognitive Functions of Children with Attention Deficit Hyperactivity Disorder (ADHD)
}

Negin Motamed Yeganeh"1, Gholamali Afrooz ${ }^{2}$, Mohsen Shokoohi Yekta², Ali Akbar Arjmandnia ${ }^{3}$, Rachel Weber ${ }^{4}$

1. Ph.D. of Psychology, Department of Psychology and Education of Exceptional Children, Faculty of Psychology and Education, University of Tehran, Iran

2. Professor, Department of Psychology and Education of Exceptional Children, Faculty of Psychology and Education, University of Tehran, Iran

3. Associated Professor, Department of Psychology and Education of Exceptional Children, Faculty of Psychology and Education, University of Tehran, Iran

4. Assistant Professor, Department of Educational Psychology and Special Education, Faculty of Education, University of British Columbia, Vancouver, Canada

Citation: Motamed Yeganeh N, Afrooz G, Shokoohi Yekta M, Arjmandnia AA, Weber R. the effectiveness of parent based metacognitive executive functions training on behavioral symptoms and cognitive functions of children with attention deficit hyperactivity disorder (adhd). Quarterly Journal of Child Mental Health. 2020; 7(3): 142-154.

http://dx.doi.org/10.52547/jcmh.7.3.12

\section{A R T I C L E I N F O}

\section{Keywords:}

Attention Deficit

Hyperactivity Disorder

(ADHD),

executive functions, parent based game, behavioral symptoms, primary school child

Received: 27 Dec 2018

Accepted: 10 Jun 2019

Available: 7 Dec 2020

\section{A B S T R A C T}

Background and Purpose: Children with Attention Deficit Hyperactivity Disorder (ADHD) experience many problems in executive functions which later may result in numerous negative consequences in different dimensions. Therefore, this study was conducted to investigate the effectiveness of parent based metacognitive executive functions training on behavioral symptoms and cognitive functions of children with ADHD.

Method: This study was quasi-experimental in the methodology with a control group pretest-posttest design. The population included all the $1^{\text {st }}$ to $3^{\text {rd }}$ grade primary school students aged 7 to 10 in Tehran in the academic year 2018-2019. Among them, 40 students together with their mothers were selected by purposive sampling and then randomly divided into the two groups, the experimental and the control group. Mothers of the experimental group received twelve 2-hour sessions of metacognitive executive functions training whereas the mothers in control group $(\mathrm{n}=20)$ were placed in the waiting list. SNAP-IV Rating Scale (Swanson, Nolan and Pelham, 1983) and CNS Vital Signs Neurocognitive Assessment (Gualtieri \& Johnson, 2006) were used to gather the data. Then, data were analyzed by Multivariate analysis of covariance (MANCOVA).

Results: Results showed that metacognitive executive functions training was significantly effective in decreasing the behavioral symptoms $(\mathrm{F}=24.782)$ and increasing the cognitive functions (working memory: $F=32.130$ and cognitive flexibility: $F=6.053$ ) of children with ADHD.

Conclusion: By using game based activities structurally managed by the parents, this therapeutic method targets dimension of executive functions which are important in the management of cognition and behavior; hence it can improve the cognitive and behavioral symptoms in children with ADHD.

\footnotetext{
* Corresponding author: Negin Motamed Yeganeh, Ph.D. of Psychology, Department of Psychology and Education of Exceptional Children, Faculty of Psychology and Education, University of Tehran, Iran.

E-mail addresses: Negin.motamed@ut.ac.ir
} 


\title{
اثربخشى آموزش كنشهاى اجرايى فراشناختى والد محور بر نشانكان رفتارى و كنشهاى شناختى كود كان

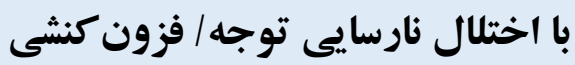

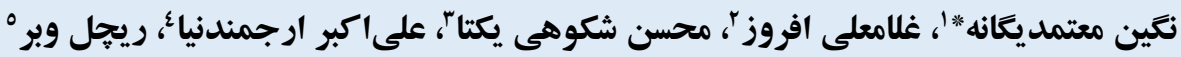

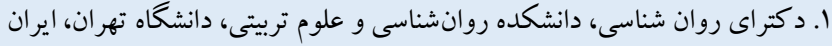

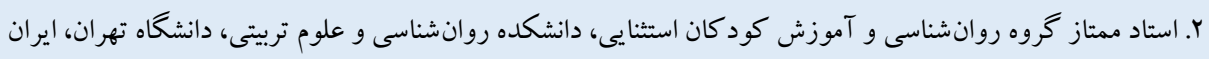

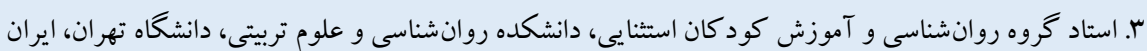

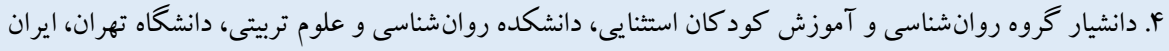

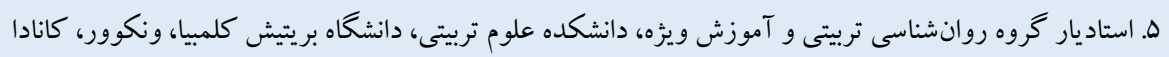

\section{جكيده}

زمينه و هدف: كود كان با اختلال نارسايى توجه / فزون كنشى مشكلات زيادى در حيطه كنش هاى اجر ايى دارند كه مىتواند بيامدهاى منفى بسيارى در ابعاد مختلف در سنين بعدى براى آنها ايجاد كند. بدين ترتيب يزوهش حاضر به منظور بر رسى اثربخشى برنامه آموزش كنشهاى

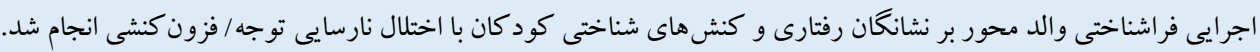

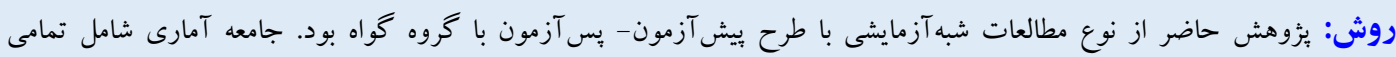

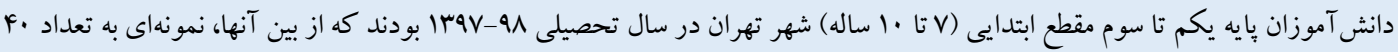

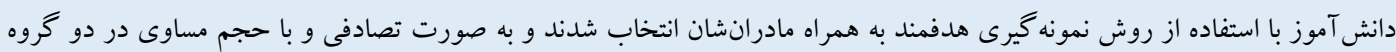

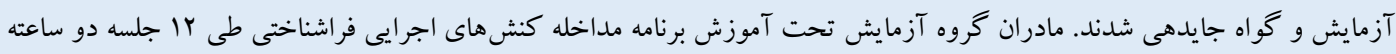

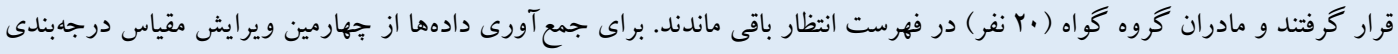

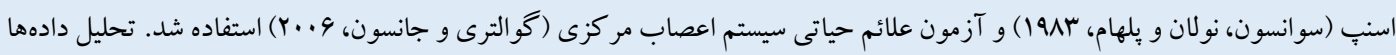
با استفاده از روش تحليل كوواريانس جندمتغيرى انجام شد.

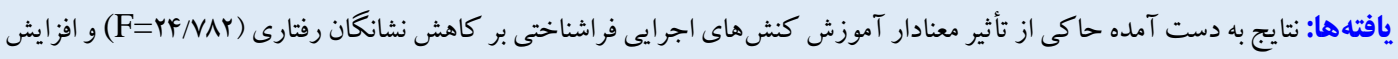

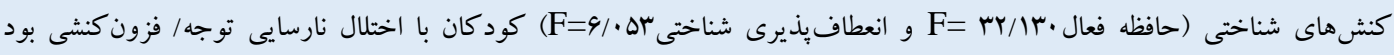

$$
(\mathrm{P}<\cdot / \cdot \Delta)
$$

نتيجه كيرى: در اين روش درمانى با استفاده از فعاليتهاى مبتنى بر بازى كه به صورت ساختارى توسط والدين اداره مى شود، جنبههايى

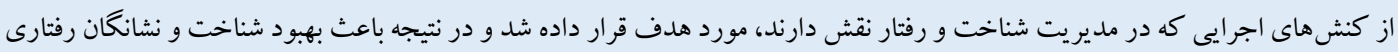

مشخصات مقاله

كليدوازهها: اختلال نارسايى توجه / فزون كنشى، إسكا،

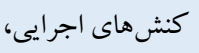
بازى والد محور، نشانغان رفتارى، كود كى دبستانى

* نويسنده مسئول: نخين معتمديگانه، دانشكده روانشناسى و علوم تربيتى، دانشگاه تهران، ايران.

رايانامه: Negin.motamed@ut.ac.ir تلفن: r| 
آزمونهاى سنجش كنشهاى اجرايى در مقايسه با كود كان فاقد اختلال،

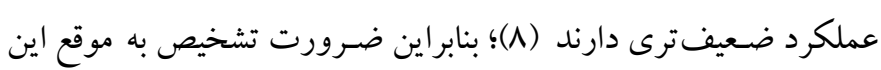

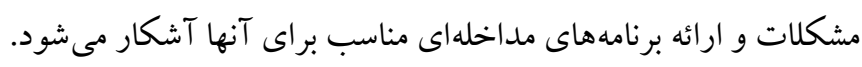

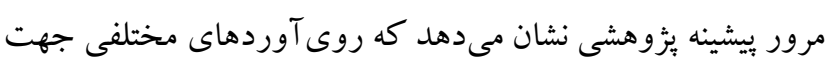

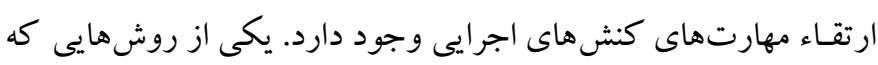

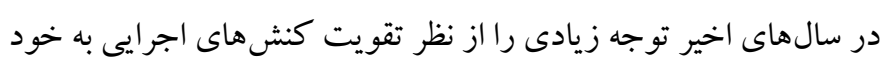

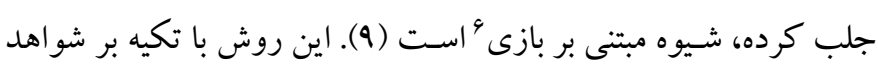

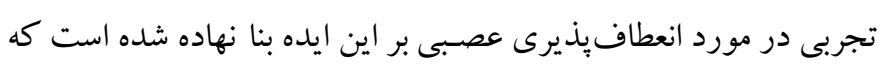

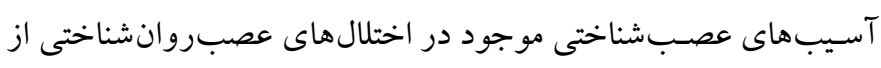

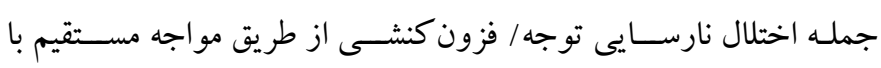

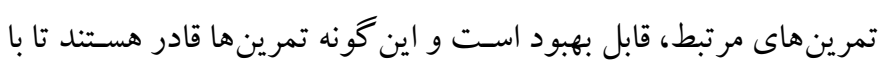
تقويت شبكه هاى عصبى، نشانهاى اختلال نارسايى توجه / فزون كنشى را

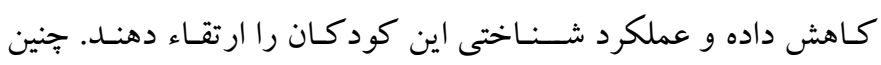

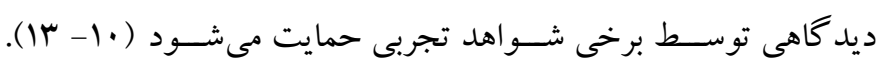

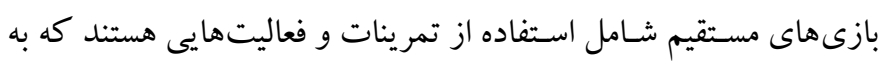

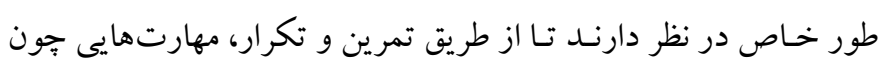

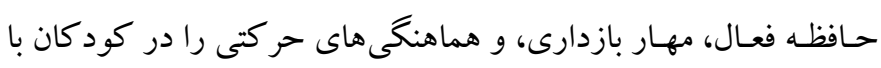

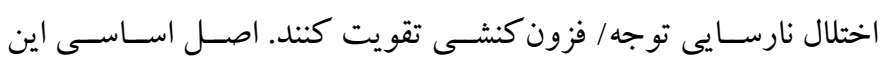

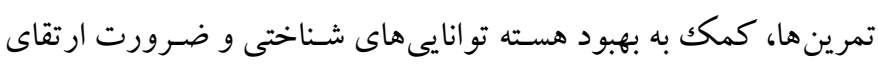

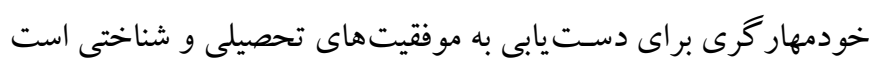

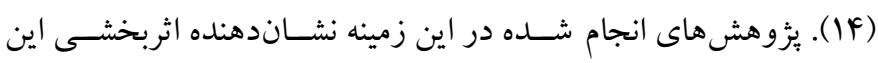

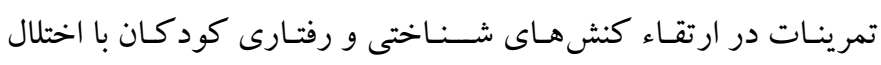

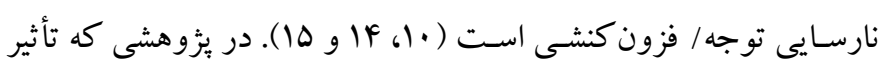
آموزش بـازىهـاى كنشهاى اجر ايى طى 9 هفته با وع كود كك با اختلال

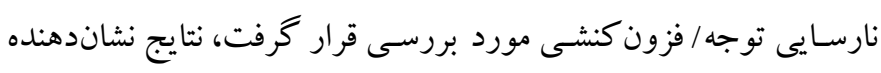

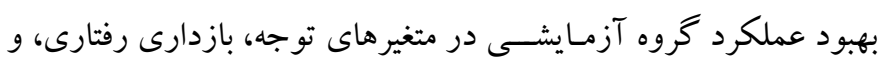

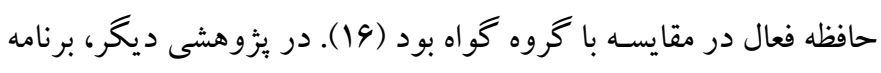

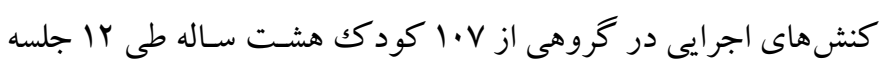

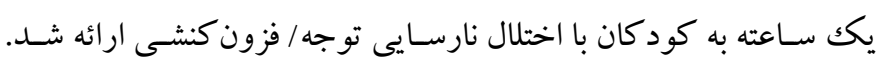

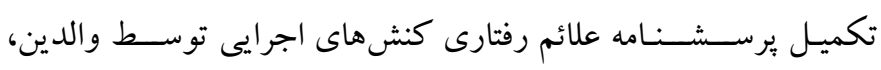

4. Inhibition

5. Cognitive Flexibility

6. Game-based Approach
مقلدمه

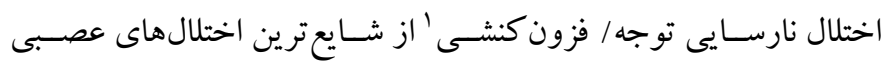

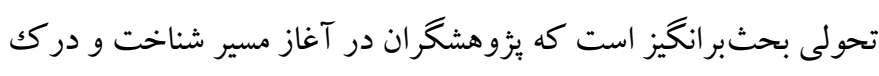

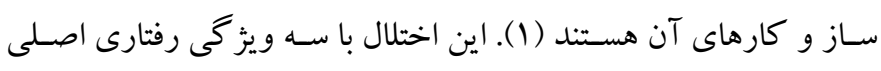

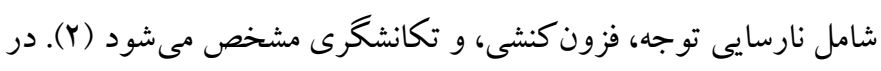

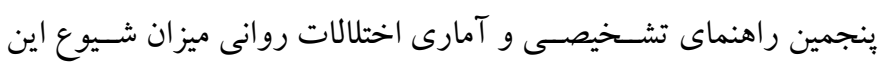

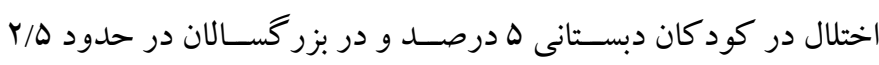

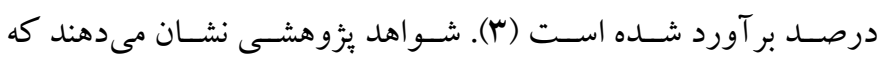

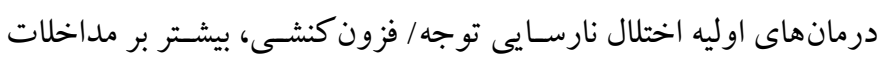

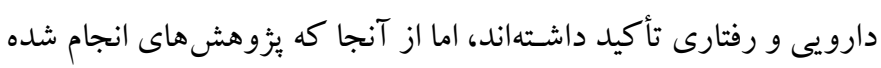

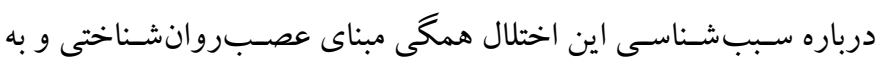

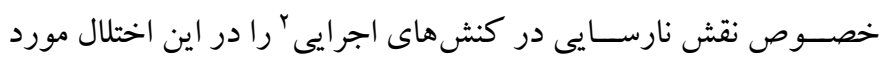

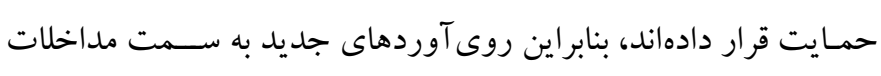

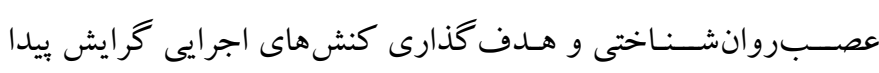

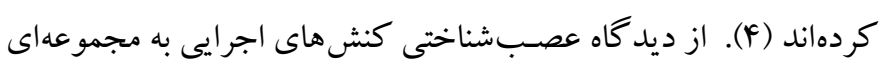

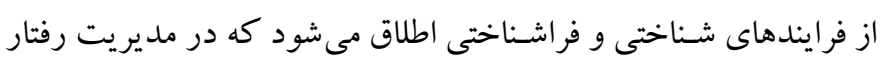

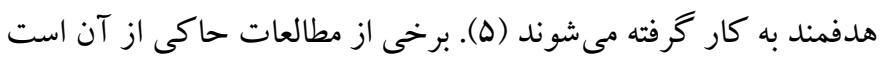

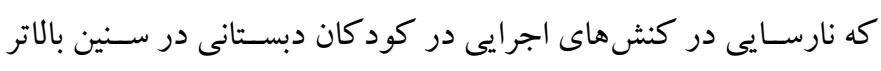

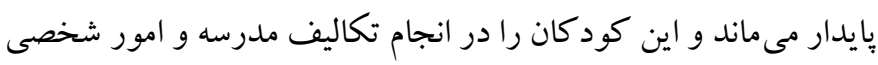

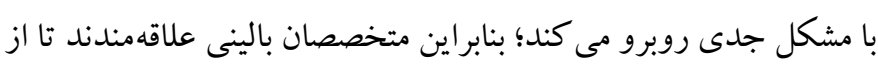

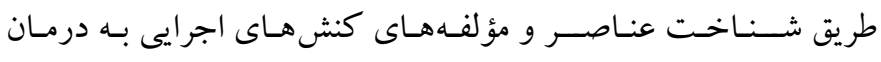

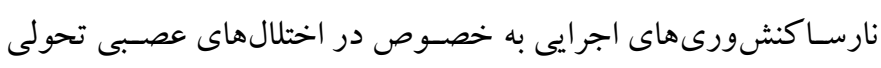

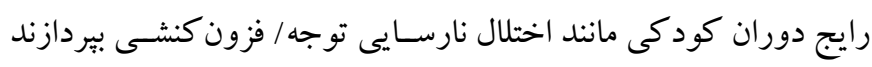

اكرجّهـ در مورد مؤلفـهــاى كنشهـاى اجرايى اتفـاق نظر كلى بين

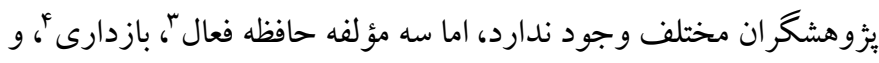

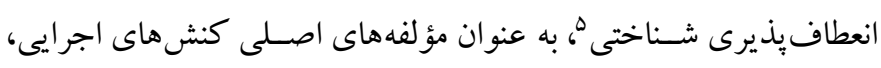

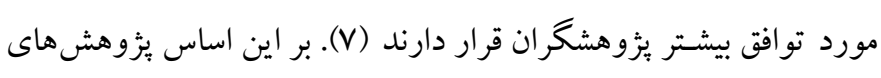

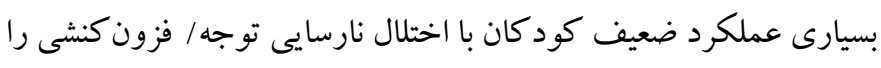
در كنشهاى اجرايى بررسى كرده و نشـان دادهاند كه اين كود كان در

1. Attention Deficit/ Hyperactivity Disorder

2. Executive Functions

3. Working Memory 
خانو ادهمحور را در كود كان با اختلال نارسـايى توجه / فزون كنشسى مورد

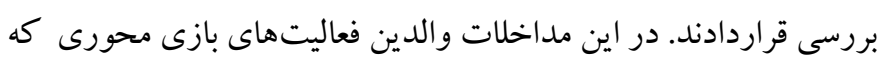

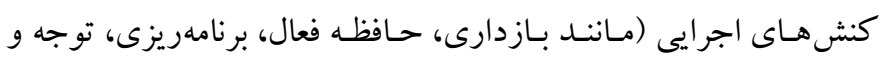

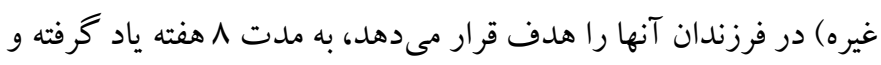

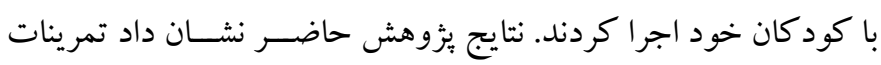

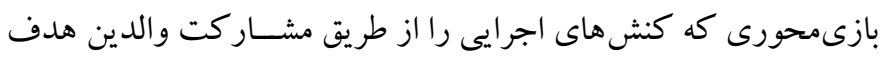

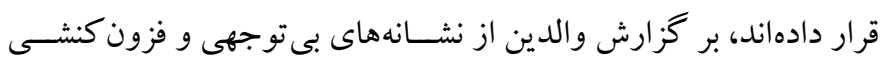

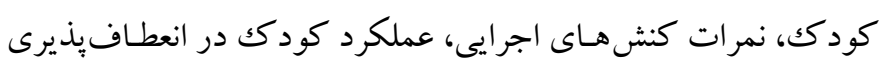

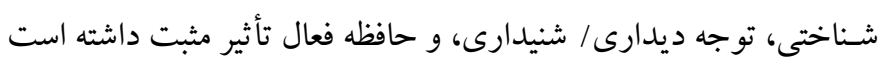

بر اين اسـاس مشـار كت مكرر والدين در انجام مداخلات بازىمحور غير كامبيوترى بـه وضـوح بتـانسـيل بالقوهاى را براى ايجاد يكك زبان

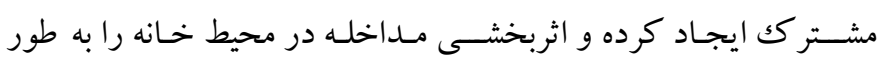

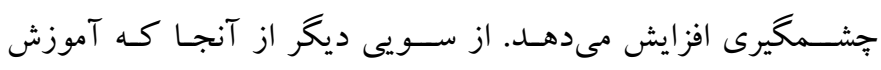

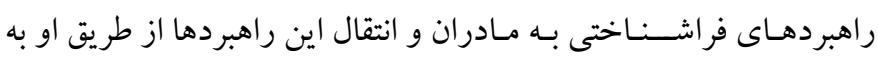
كودك، زمينه افزايش ياد گيرى و انكيزش بيشرفت را در كود كك فراهم

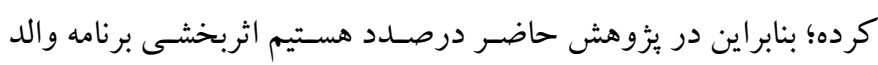

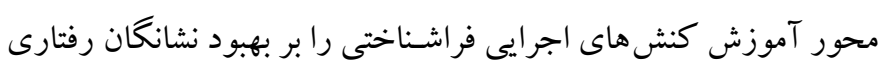

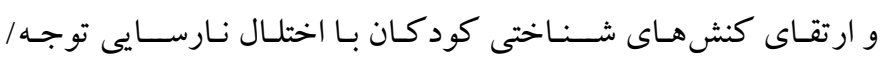

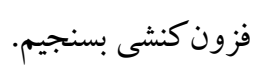

روش

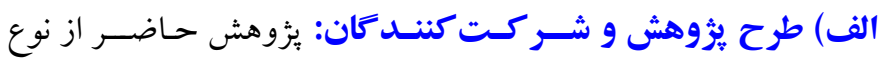

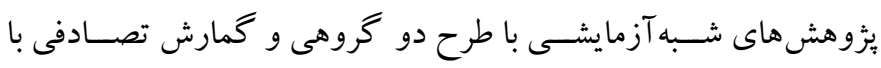

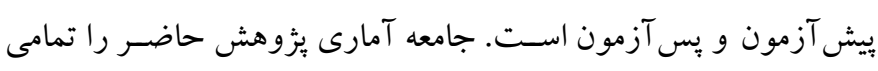

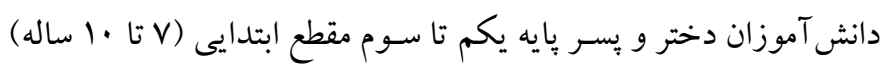

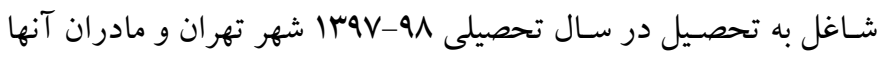
تشكيل مى هند. با استفاده از روش نمونه گيرى غير تصادفى هدفمند، از

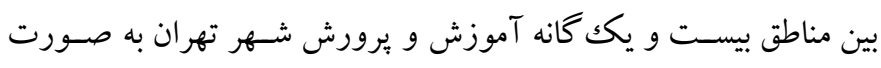

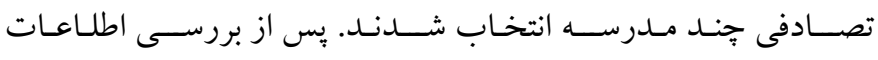

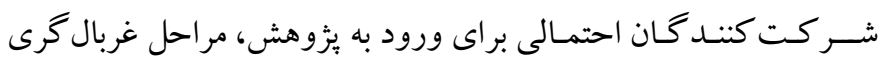

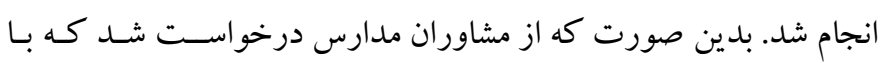

اثربخشـى اين تمرينها را در تمامى حيطههاى كنشهاى اجر ايى نشــان

داده است (IV) ( ) (IV)

علـاوه بر اهميـت كنشهـاى اجرايى، يثزوهشهاى مختلف نشــان

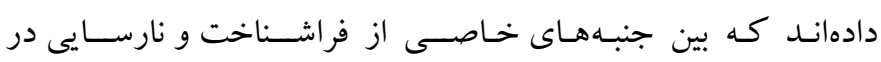
تو انمنـدىهـاى شــنـاختى و رفتارى كود كان با اختلال نارســايى توجها

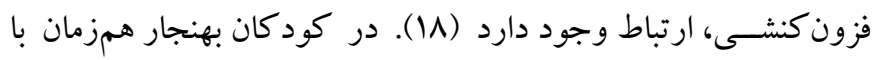

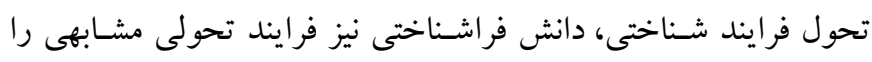

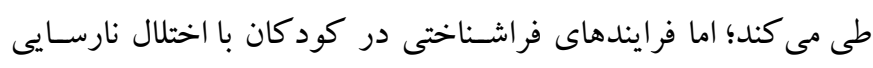

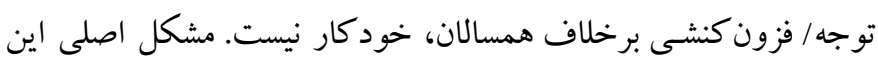

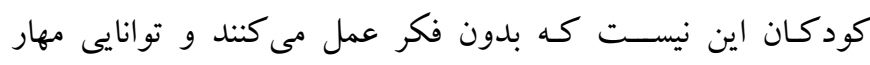

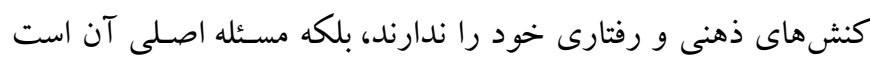

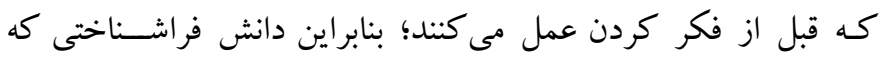

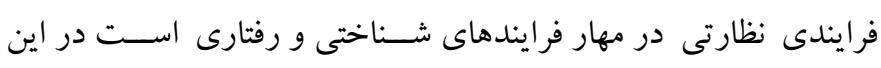

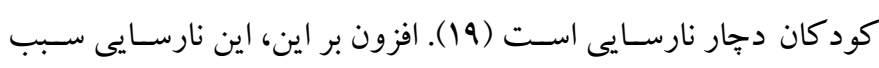

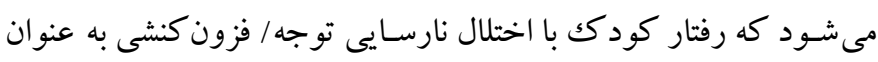

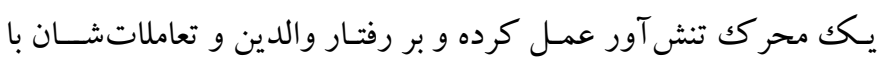

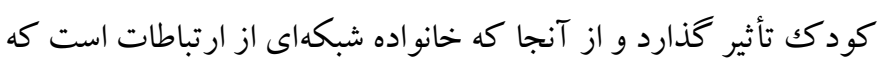

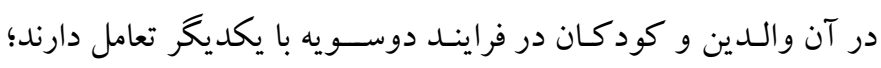

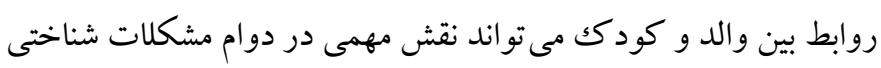

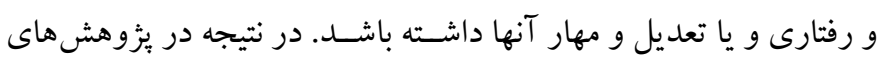

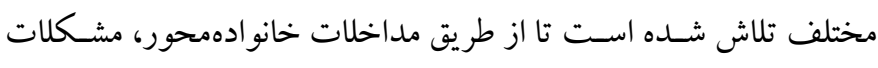

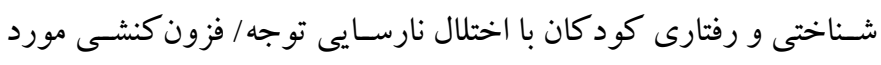

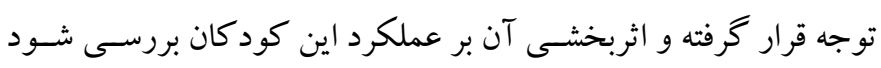
$\left(Y r^{-} r_{\cdot}\right)$

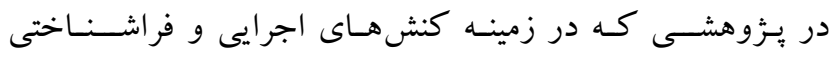

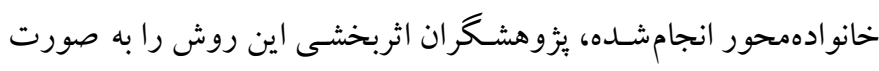

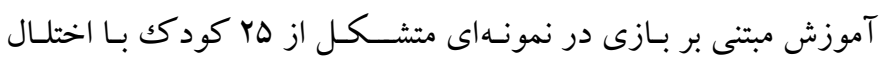

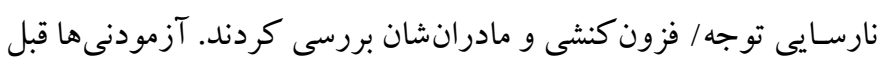

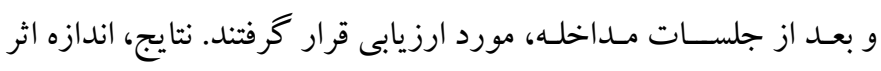
متوسط را در درجهبندى والدين در حيطه نشانگان رفتارى و بهبود نمرات

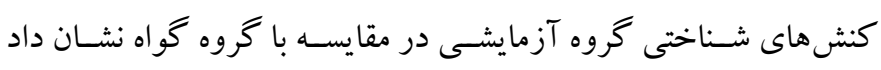

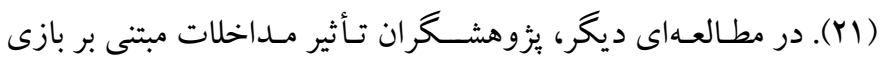




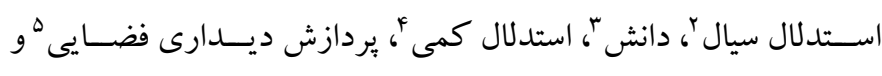

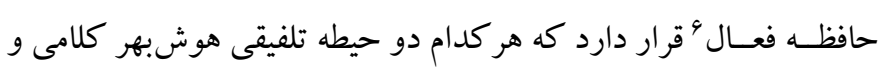

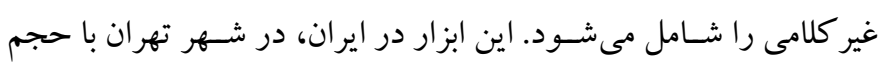

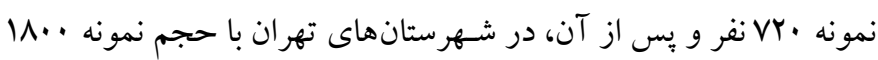

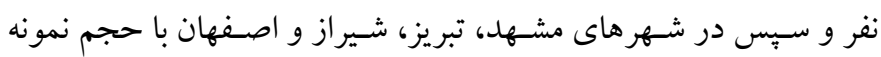
rF.. را در مردم ايران نشان داده است. هوش آزماى نوين تهر ان استنفورد بينه،

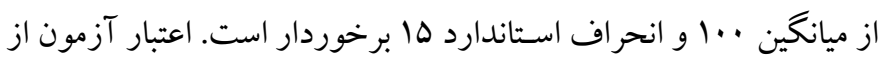

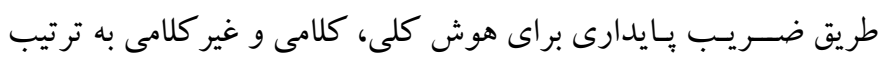

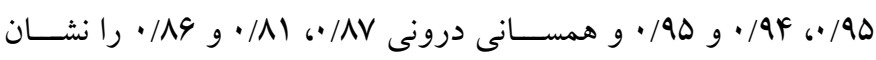

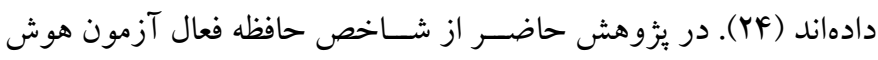
تهران استنفورد بينه جهت شناسايى افر اد با عملكرد بِيين در حافظه فعال

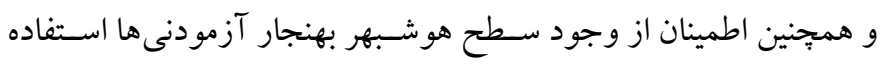

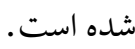

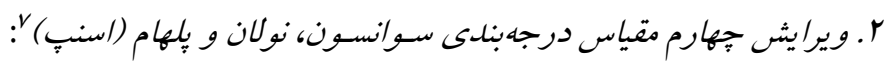

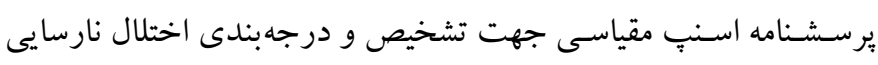

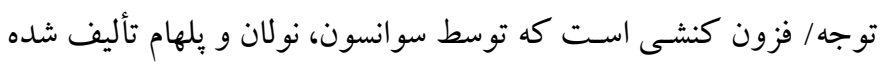

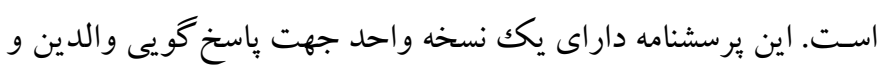

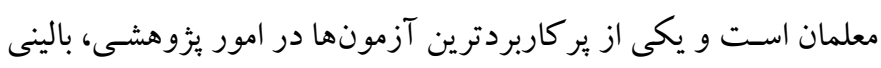

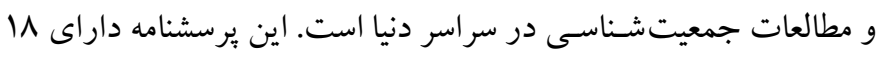

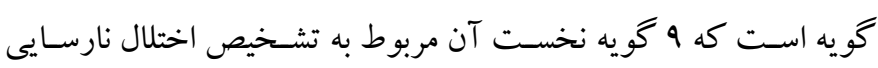
توجه و ه گويه دوم مربوط به تشخيص اختلال فزون كنشى است؛ بنابر اين

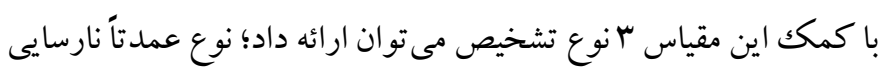

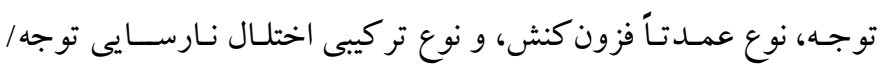

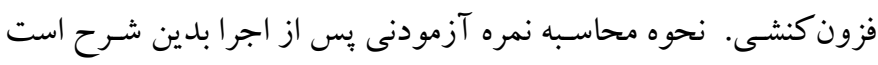

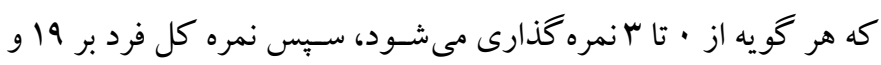

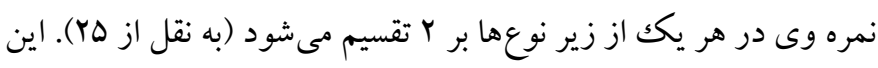

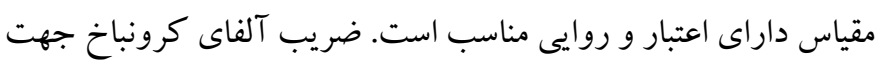

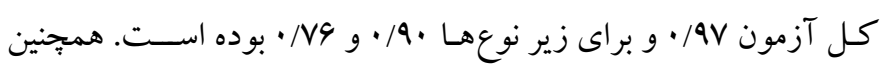

7. The SNAP-IV Parent Rating Scale
توجه به آشــنايى با ســـوابق رفتارى و يا مر اجعه به بروندههاى مشــاوره

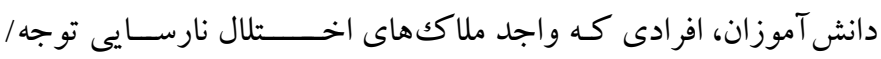

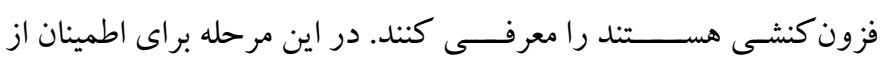
تشـخيص صحيح و بررسى معيارهاى ورود و خروج، مصاحبه بالينى نيمه

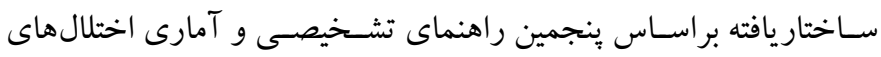

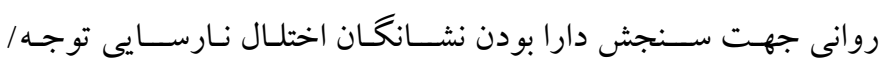

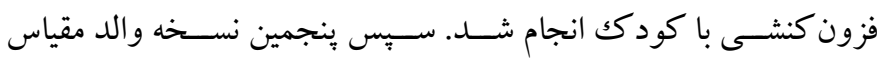

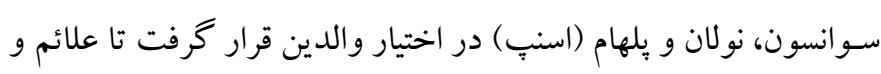

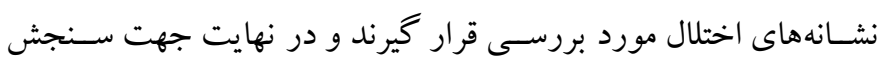

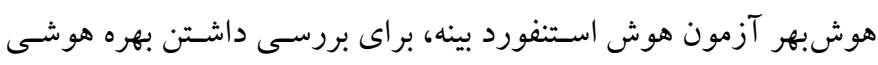

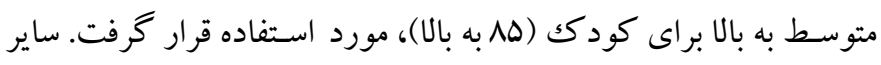

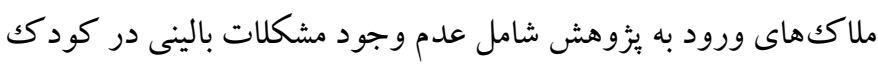
و مادر بر اساس مصاحبه تشخيصى، عدم مصرف دارو براى كود كك، دارا

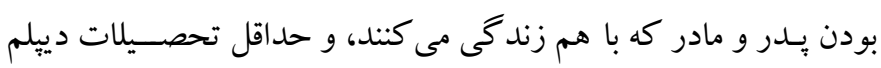

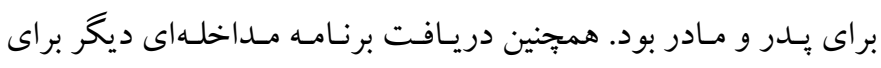

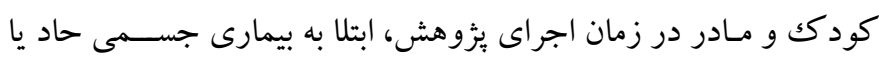

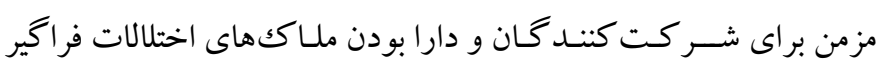

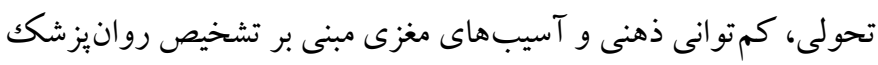

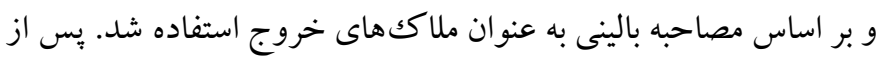

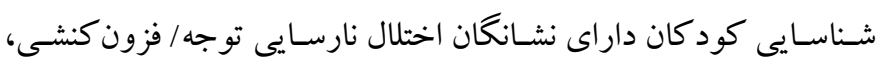

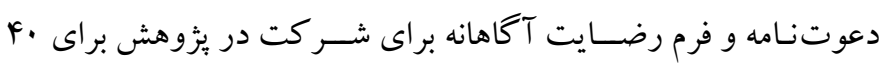

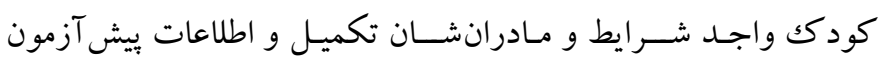
جمع آورى شد. ب) ابزار: در بزوهش اورى حاضر از ابزارهاى زير براى گردآورى اطلاعات استفاده شد.

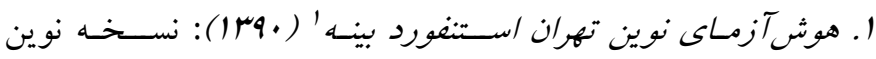

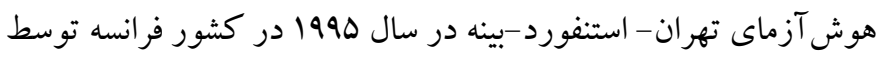

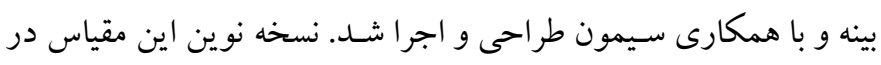

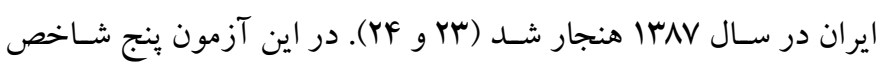

1. Tehran- Stanford- Binet Intelligence Scale

2. Fluid reasoning

3. Knowledge

4. Quantitative reasoning 
شناختى، همبستخى هايى را نشان مىدهد كه قابل مقايسه با روايى همزمان

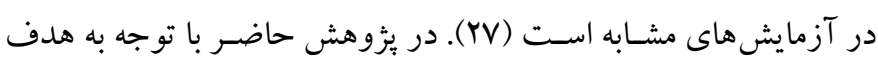

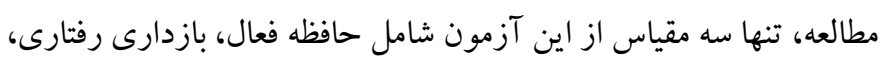

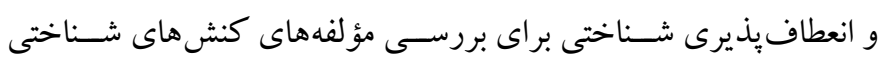
استفاده شده است.

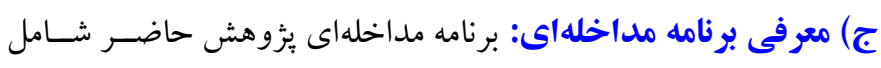

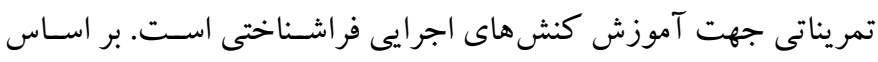

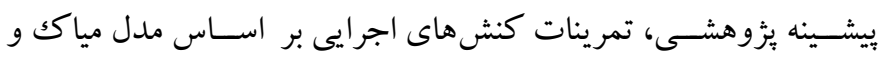

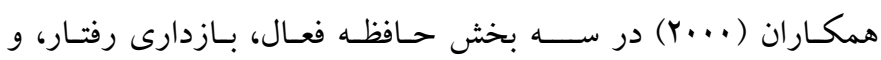
انعطاف يذيرى شناختى طراحى شد. تمرينات فراشناختى نيز عبارتاند از:

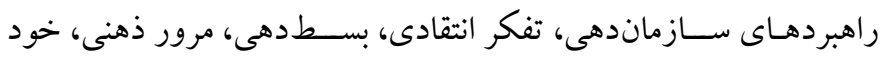

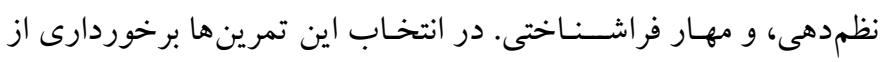

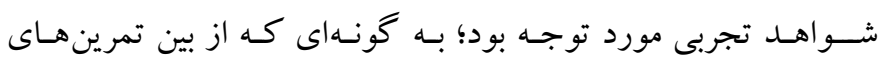

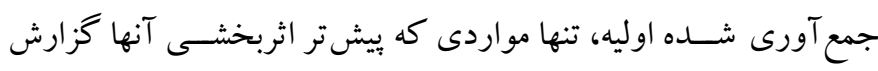

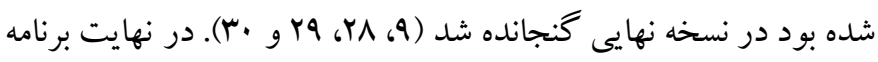
آموزش كنشهاى اجرايى فراشـناختى، طى Y ا جلسه Y ساعته به صورت

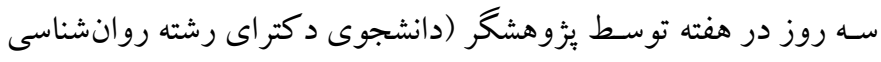

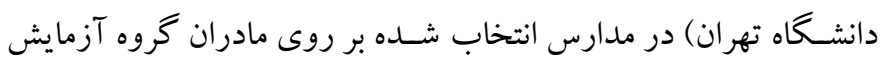

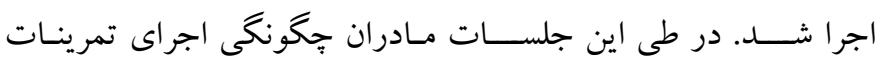

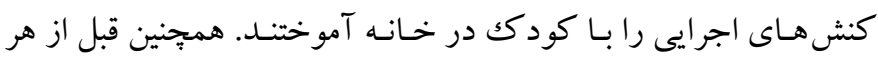
فعاليت نحوه اسـتفاده از راهبردهاى فراشــناختى كه موجب فعال شــــن كنشهاى اجر ايى مورد نظر در كودكك مى شود براى مادران توضيح داده و مدلسـازى شـد. در جدول الهدف هاى آموزشسى و نام فعاليتها ارائه
صــر السـادات و همكاران (Y) ضـريب اعتبار آزمون را با اســفاده از شـيوههاى باز آزمايى، آلفاى كرونباخ و ضـريب دو نيمه كردن به ترتيب

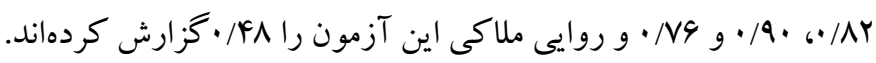

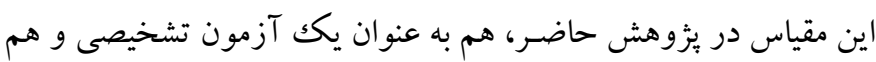

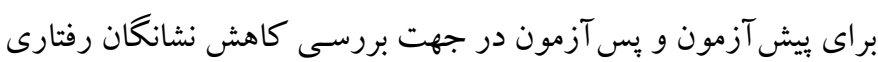

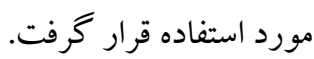

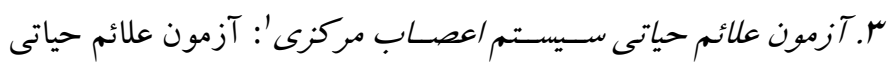

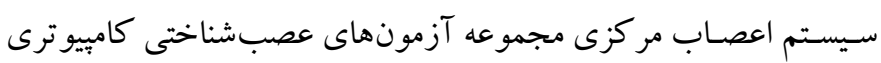

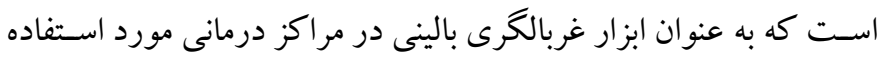

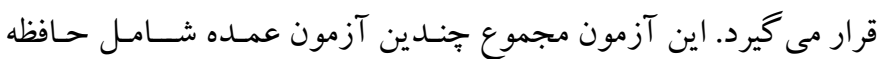

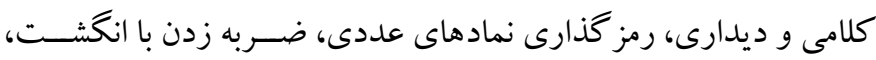

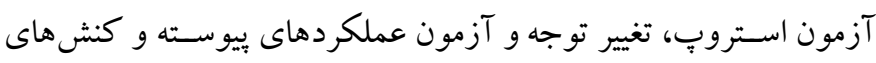

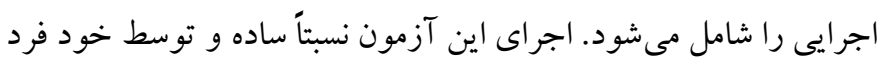

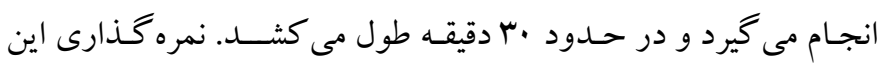

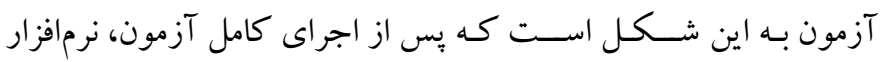

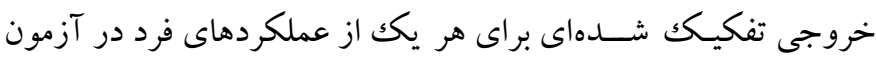

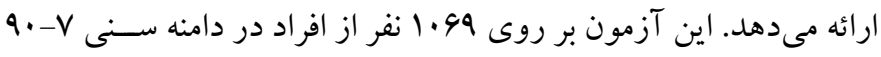

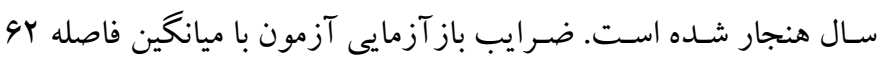

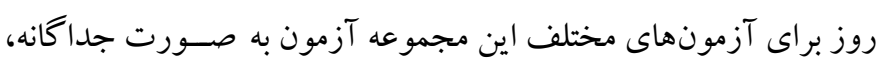

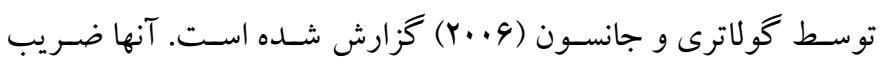

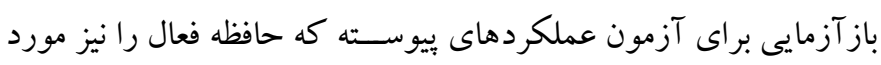

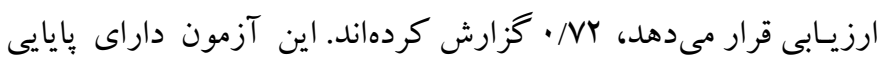

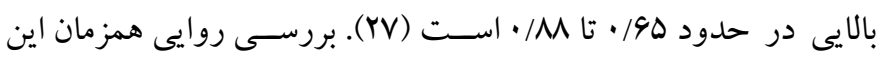

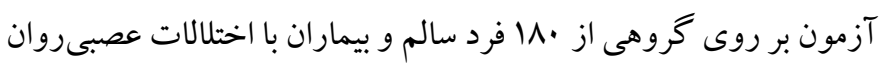

\begin{tabular}{|c|c|}
\hline محتوا & جلسه \\
\hline معارفه و معرفى برنامه & يكم \\
\hline آشنايى با اختلال نارسايى توجه/ فزون كنشى و مشكلات شناختى و رفتارى اين كود كان & دوم \\
\hline نقش كنشهاى اجرايى و فراشناختى در اين اختلال & 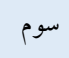 \\
\hline آموزش اصول رابطه مادر -كودكى & 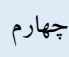 \\
\hline بازى تعاملى مشتر كك مادر-كودكى & ينجم \\
\hline
\end{tabular}




\begin{tabular}{|c|c|c|c|}
\hline 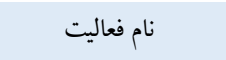 & هدف آموزشى كنشهاى اجرايى & هدف آموزشى فراشناختى & \\
\hline بازى حافظه & حافظه فعال & & \\
\hline بازى گرگك و گ سفند & بازدارى رفتار & سازماندهى & ششم \\
\hline بازى قلبها و كل ها & انعطاف يذيرى شناختى & & \\
\hline بازى مزرعه حيوانات & حافظه فعال & & \\
\hline بازى فلانكر & بازدارى رفتار & تفكر انتقادى & 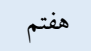 \\
\hline بازى كارتها & انعطاف يذ يرى شناختى & & \\
\hline بازى جام جادويى & حافظه فعال & & \\
\hline بازى برو و نرو & بازدارى رفتار & 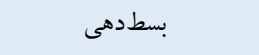 & 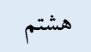 \\
\hline بازى كوادراتو & انعطاف يذيرى شناختى & & \\
\hline بازى ضربه زدن & حافظه فعال & & \\
\hline بازى سايمن & بازدارى رفتار & 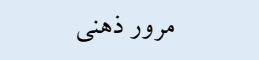 & نهم \\
\hline بازى سر ينجه شانه زانو & انعطاف يذيرى شناختى & & \\
\hline بازى داخل و خارج & حافظه فعال & & \\
\hline بازى روز و شب & بازدارى رفتار & خود نظم دهى & دهم \\
\hline بازى ساعات شلوغ & انعطاف يذيرى شناختى & & \\
\hline بازى تقليد كردن & حافظه فعال & & \\
\hline بازى آنتى ساكاد & بازدارى رفتار & كنترل فراشناختى & يازدهم \\
\hline بازى شكل و رنك & انعطاف يذيرى شناختى & & \\
\hline 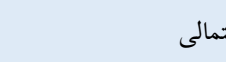 & ييخيرى روند اجراى آمو & & دوازدهم \\
\hline
\end{tabular}

ماندن اطلاعات، به طور كامل رعايت شــــ. تحليل دادهها با اســتفاده از روش تحليل كوواريانس جندمتغيرى و از طريق نســه بيسـت و جهارم

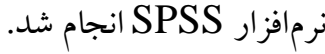

يافته ها ميانگين و انحر اف معيار متغير هاى سـن، ميزان هوشبهر، تحصيلات مادر

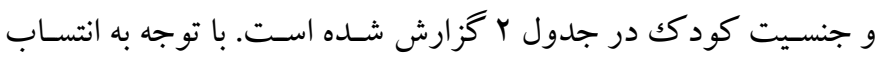

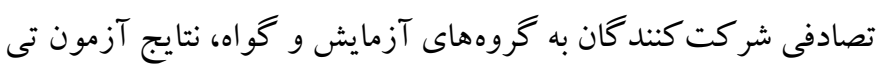

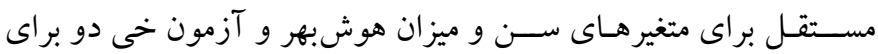
متغير هاى تحصيلات مادر و جنسيت كود كى، مؤيد همسانى گروهها است

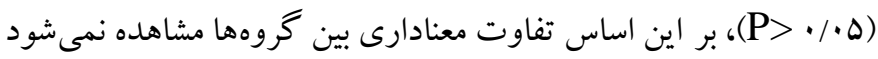

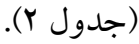

د) روش اجرا: پِ از كسب مجوزهاى علمى و اجرايى لازم از دانشگاه تهران و اداره آموزش و برورش شهر تهران، افراد نمونه به شرحى كه در بخش روش ارائه شـد، انتخاب و با تخصيص شماره به اسامى به صورت تصادفى در گروههاى آزمايش و گو اه جايدهى شـدند (شمارههاى زوج

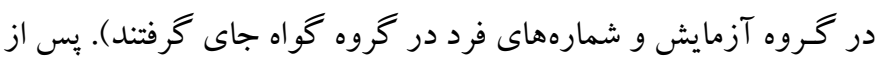

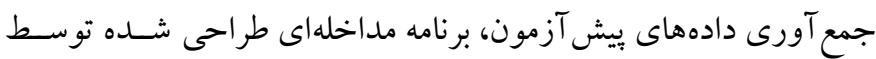

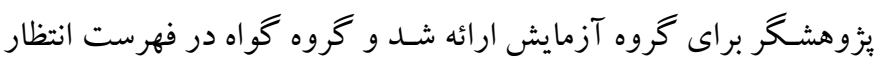

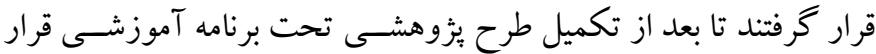

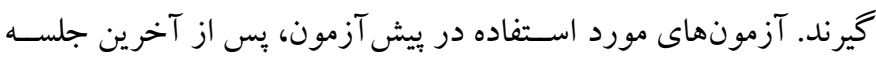

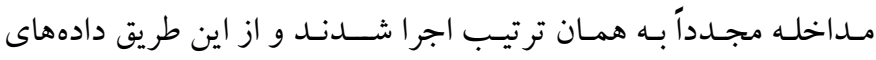

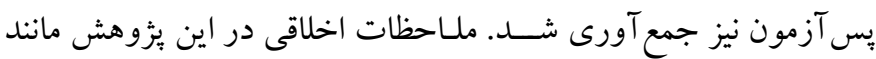
موافقت و رضـايت كتبى افراد نمونه، رعايت اصـل رازدارى و محرمانه 
جدول r: شاخصهاى توصيفى مربوط به ويز كىهاى جمعيت شناختى نمونه يخوهش

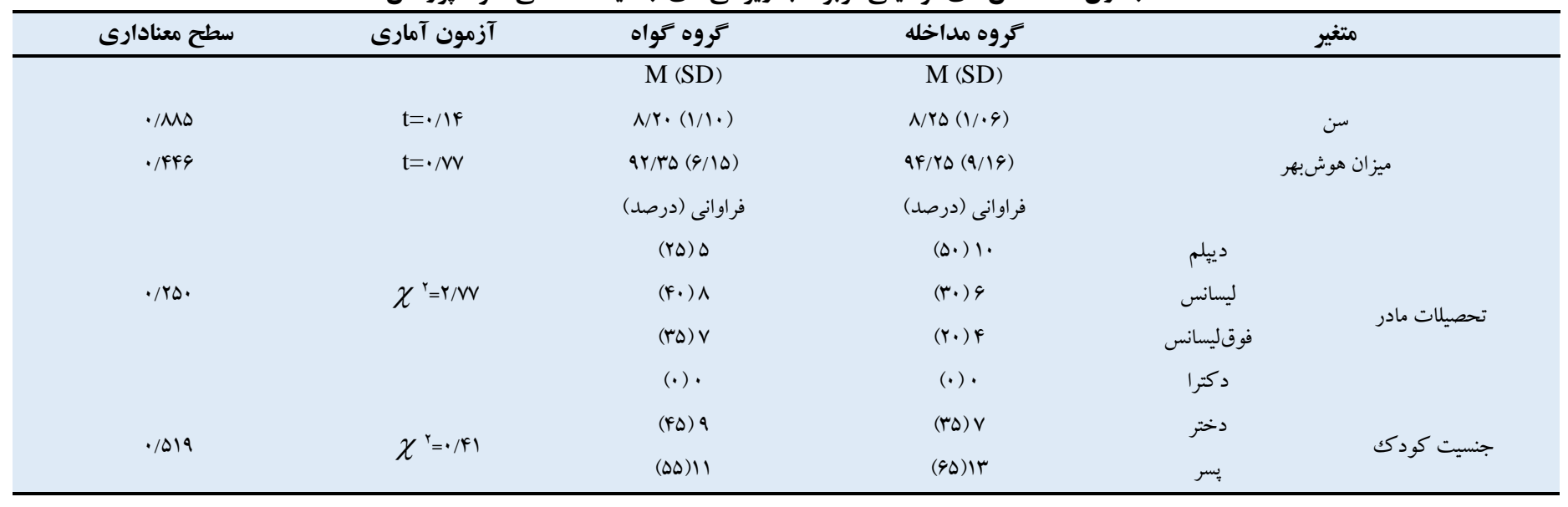

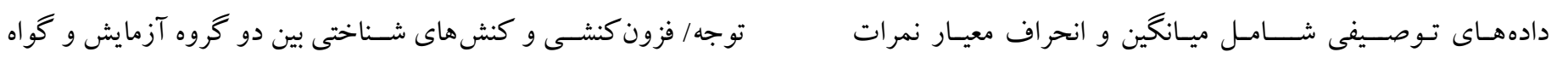

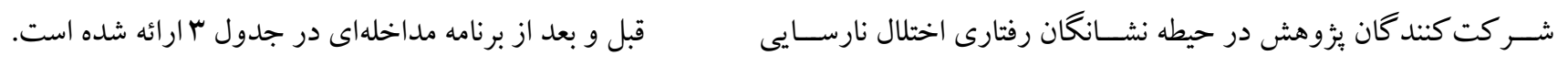

جدول بّ: شاخصهاى توصيفى متغير هاى وابسته قبل و بعد از برنامه مداخله در دو كروه آزمايش و كواه

\begin{tabular}{|c|c|c|c|c|c|c|c|}
\hline \multirow[t]{2}{*}{ Pقدار Pa } & \multicolumn{2}{|c|}{ يس آزمون } & \multicolumn{2}{|c|}{ يِيش آزمون } & \multirow[t]{2}{*}{ متغير } & & \multirow[t]{2}{*}{ كروه } \\
\hline & انحر اف معيار & ميانگين & انحر اف معيار & ميانگين & & & \\
\hline$* \cdot \cdot \cdot 1$ & $F / \cdot 1$ & $I V / F V$ & $r / A r$ & $r r / q$. & بى توجهى & & \\
\hline.$/ .94$ & $r / v \wedge$ & $r \mu / .9$ & $\Delta / \cdot r$ & $r F / 19$ & فزون كنشى & نشانغان رفتارى & \\
\hline 粉. $/ \cdots 1$ & $9 / 91$ & $r \cdot / \Delta r$ & $9 / \cdot \vdash$ & $F N \cdot q$ & نشانغان كلى & & \\
\hline$* \cdot / \cdots 1$ & $9 / 19$ & $9 V / A$ & $\mathrm{~V} / \mathrm{A}$. & $\Lambda F / 9$. & حافظه فعال & & ازمايش \\
\hline$\cdot / \cdot v$ & $9 / 10$ & $9 r / r$ & $Q / \Delta r$ & $\wedge 9 / \wedge$ & 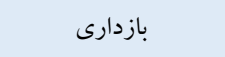 & كنشهاى شناختى & \\
\hline$* \circ / . .1$ & $\mathrm{~V} / \mathrm{V}$. & $9 \vee / 4$. & $\Lambda / F \Delta$ & $\wedge \mathrm{V} / 9 \Delta$ & انعطاف يذيرى شناختى & & \\
\hline .1 .9 & $k / r \Delta$ & $r M / \Delta \Delta$ & $\Delta / \uparrow \wedge$ & $r r / 19$ & بى توجهى & & \\
\hline$\cdot / v \cdot v$ & $F / Y$. & $r Y / \Delta \Delta$ & $\Delta / r^{Q}$ & $r Y / Y I$ & فزون كنشى & نشانگان رفتارى & \\
\hline$\cdot / \Delta \Delta V$ & $\Delta / 9 \Lambda$ & $49 / 11$ & $9 / \cdot \wedge$ & $f \Delta / F$. & نشانگًان كلى & & ه \\
\hline *. $/ .11$ & $9 / \pi \Lambda$ & $\wedge \Delta / ৭$ & $\Delta / 9 \Lambda$ & $\Lambda \cdot / \wedge \Delta$ & حافظه فعال & & \\
\hline$* / . r 9$ & V/aF & $91 / \wedge$. & $1 \cdot / 0 r$ & $\wedge 9 / 0$ & 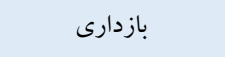 & كنشهاى شناختى & \\
\hline$* \cdot / \cdot 11$ & A/Va & $9 \cdot / 40$ & $1 \cdot 109$ & $\Lambda r / \Lambda$. & انعطاف يذيرى شناختى & & \\
\hline
\end{tabular}

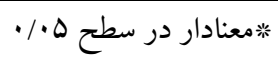

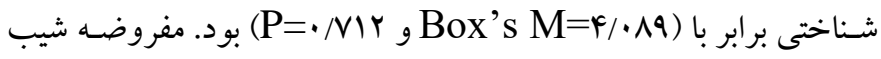
خط رگر سيون براى متغيرها و خطى بودن رابطه متغيرها برقرار بود د. نتايج

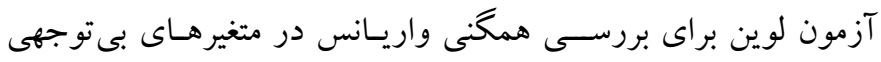

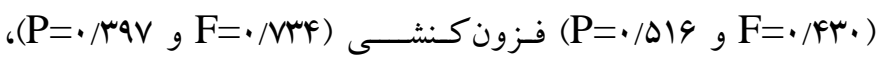

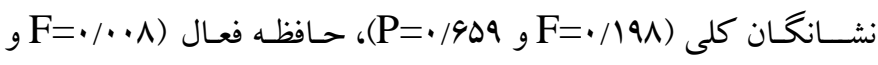
.
در ادامه براى تحليل دادههاى بزوهش و آزمون وجود يا عدم وجود

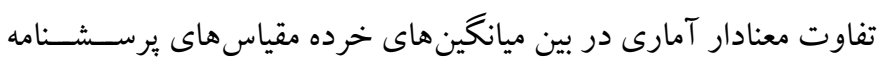

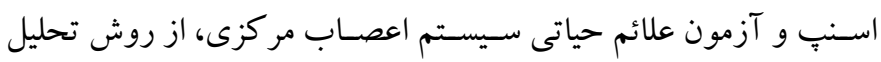

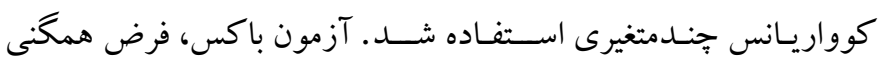
واريـانس -كواريـانس در هر دو تحليـل را تأييد كرد كه براى نشـانغانغان

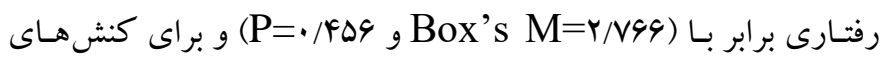




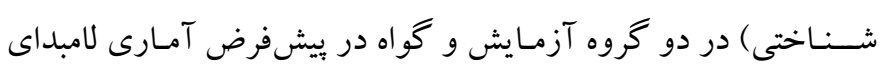

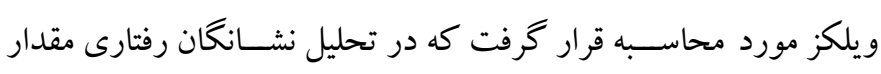

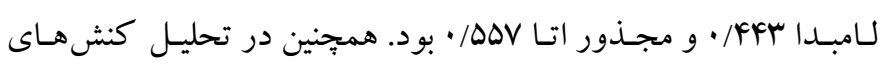

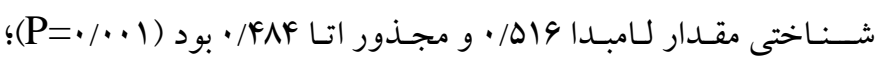

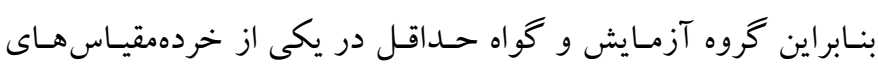

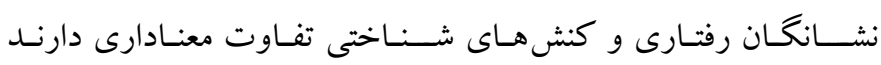

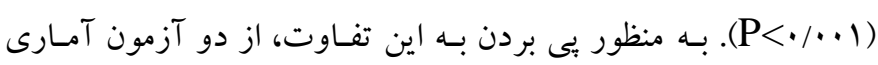

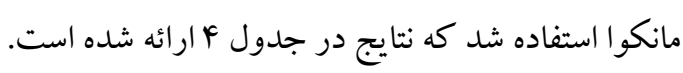

در دو گروه معنادار به دست نيامد؛ بنابر اين دو (P=•/910 و F=•/rQV)

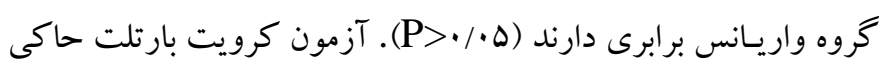

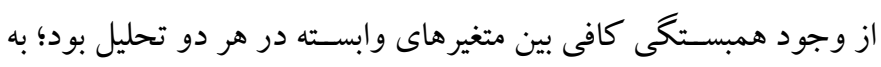

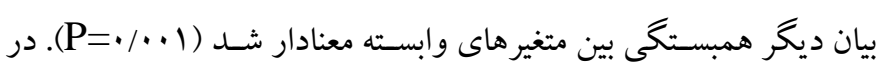

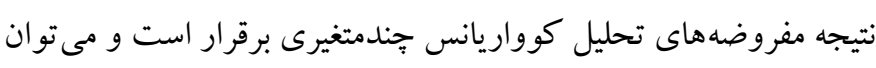

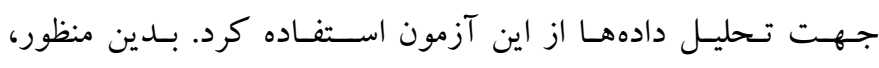

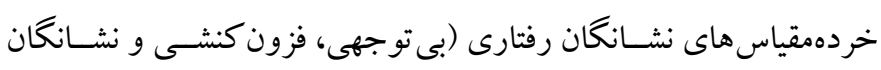

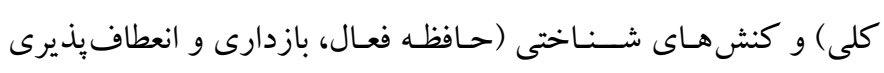

جدول ع: نتايج تحليل كوواريانس جندمتغيرى براى خردهمقياسهاى نشانكان رفتارى و كنشهاى شناختى با حذف اثر بيش آزمون

\begin{tabular}{|c|c|c|c|c|c|c|c|c|}
\hline توان آمارى & مجذور اتا & سطح معنادارى & Tاره F F F & ميانكين مجذورات & درجه آزادى & مجموع مجذورات & متغيرهاى وابسته & \\
\hline 1 & - /far & $* \cdot / \cdot \cdot 1$ & $r$ r/AVG & $m 1 . / \% 99$ & 1 & $m 1 . / \mu q q$ & بى توجهى & \\
\hline.$/ . \Delta F$ & $\cdot / \cdot 1$ & $\cdot / A \Delta 9$ & 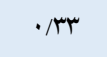 & $\cdot / r r$. & 1 & . & فزون كنشى & نشانگان رفتارى \\
\hline.$/ 991$ &.$/ 410$ & $* \cdot / \cdot 1$ & rF/VAr & $r V \Delta / F r G$ & 1 & $r V \Delta /$ Frg & نشانگان كلى & \\
\hline 1 & . / Fva & $* \cdot / \cdots 1$ & $r r / l r$. & $1 . .9 / \wedge \vee q$ & 1 & $1 \cdots q / \wedge \vee q$ & حافظه فعال & \\
\hline.$/ . \Delta \Lambda$ & $\% r$ & ./va. & $\cdot / \cdot V r$ & r/DAr & 1 & $r / \Delta \wedge r$ & بازدارى & . \\
\hline $.199 \mathrm{~V}$ &.$/ I F V$ & $* \cdot / \cdot 19$ & $9 / . \Delta r$ & $r F \cdot / A$. & 1 & $r F \cdot / \Lambda .$. & شنافيذي & \\
\hline
\end{tabular}

نشانگان رفتارى در گروه آزمايش، بعد از درمان كاهش بيدا كرده است؛

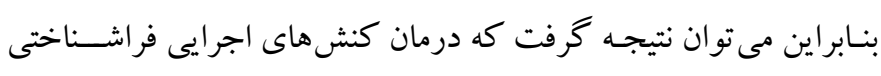

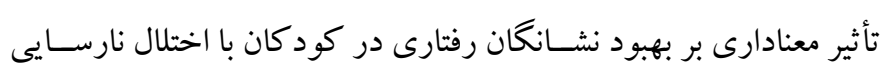

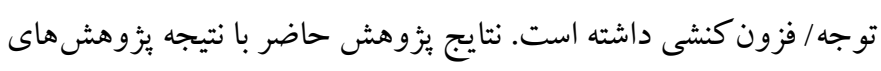

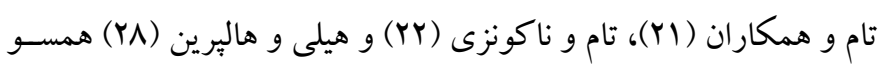

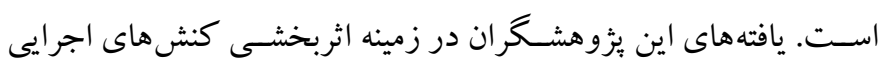

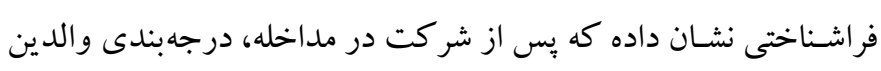
از نمرات مشكلات توجهى و نشانگان كلى كود كان كاهش داشته است دان.

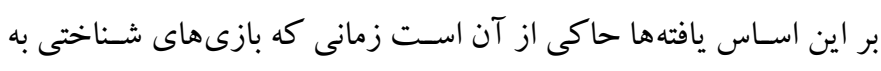

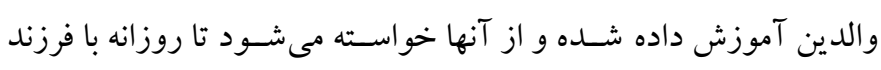

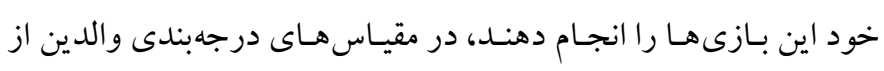

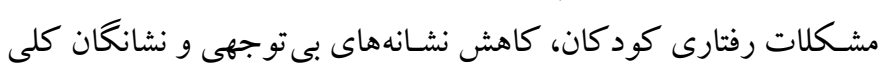

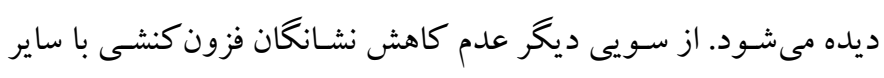

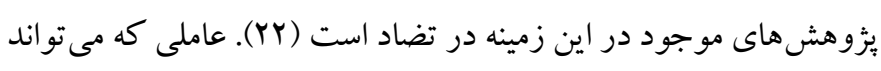

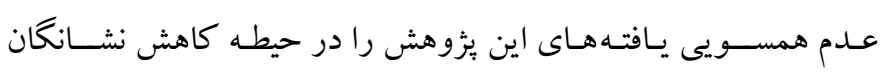

بررسـى نتايج تحليل كوواريانس جندمتغيرى نشـان داد كه مداخله ارائه

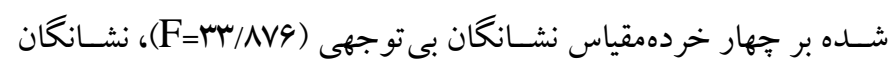

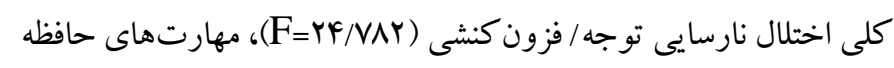

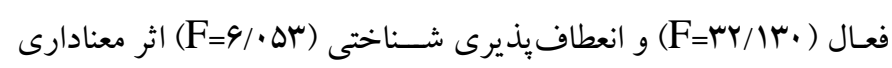

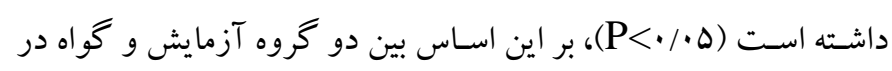

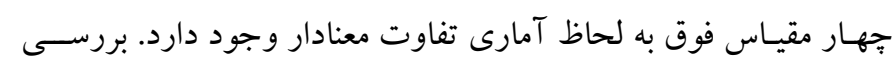

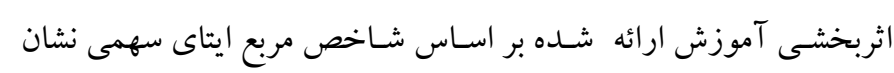

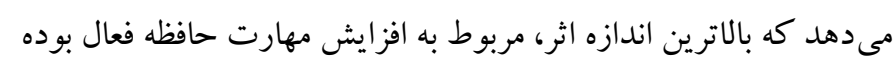

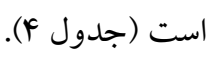

\section{بحث و نتيجه كيرى}

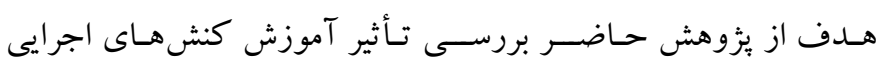

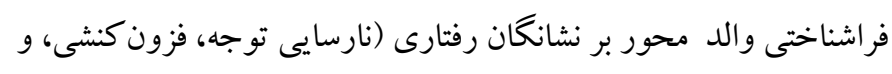

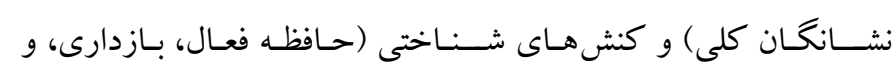

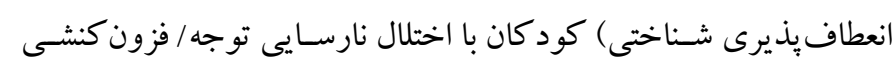

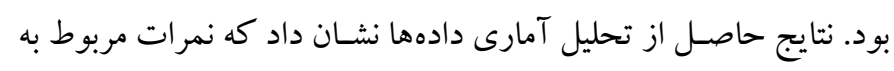


دادهاند كود كان با كنشهاى اجر ايى ضعيفتر، از برنامههايى كه هر يكك

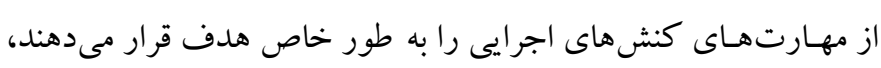

بيشتر بهرهمند مىشوند (Y) يثزوهش حاضر با توجه به فقدان مداخلات والد محور مبتنى بر شواهد

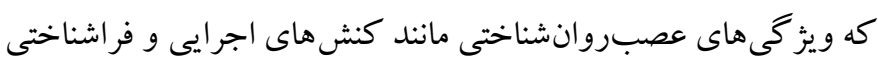

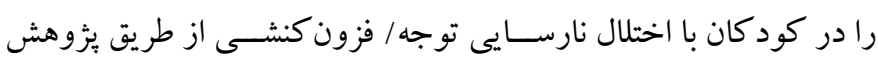

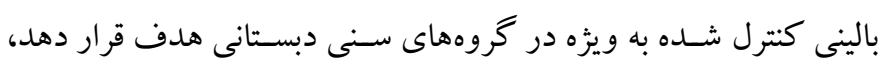

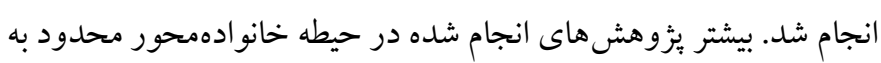

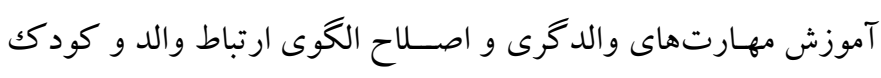

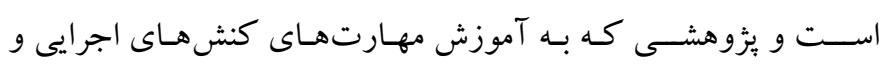

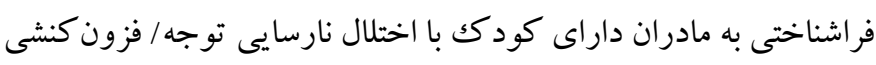

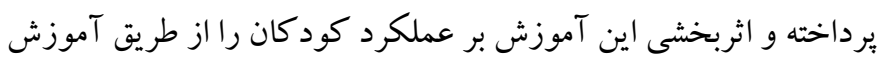

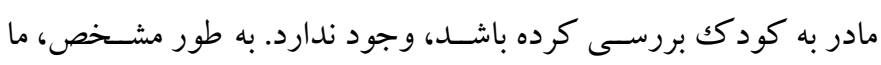

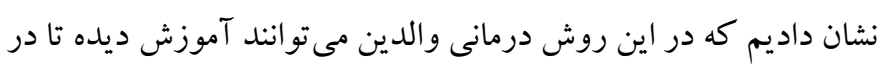

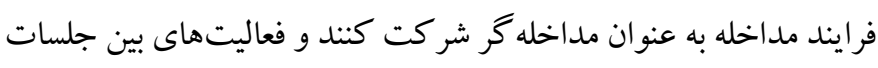

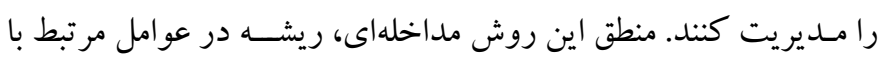
تحول كنشهاى اجرايى و يافتهاى مربوط به روانشـناسى تحولى مانى دارد

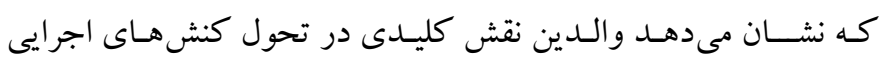

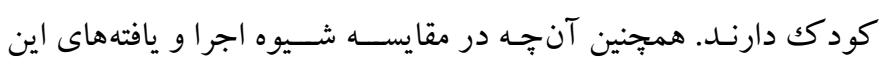

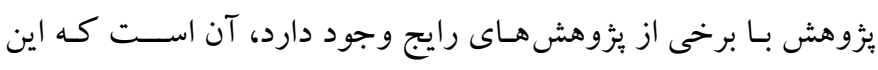

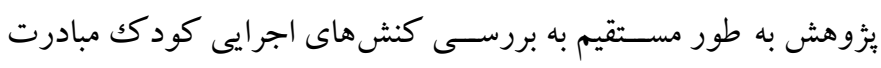

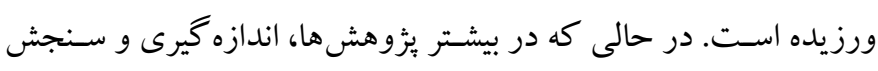

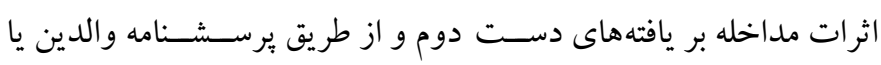

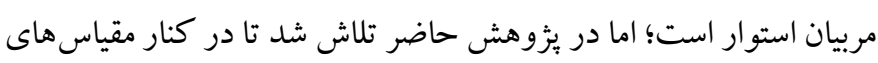

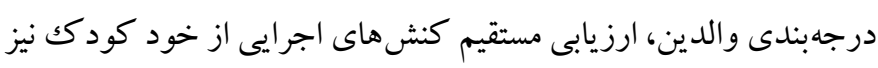

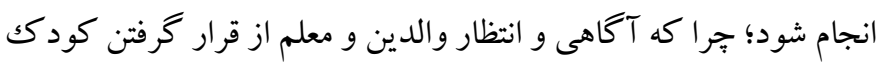

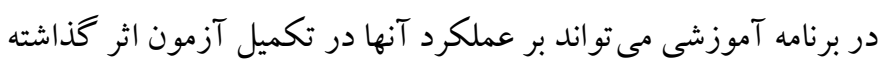

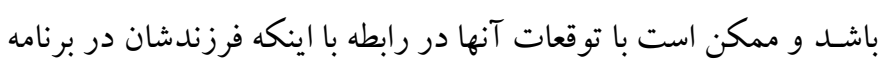

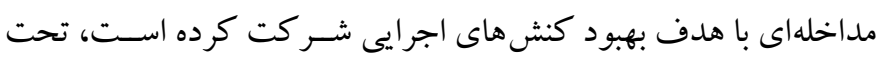

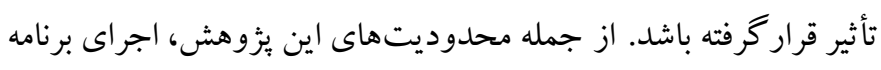

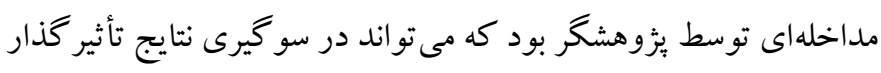

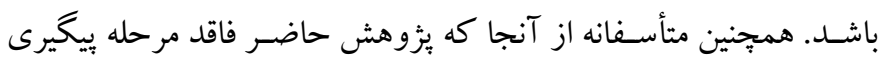

فزون كنشـى تبيين كند، به ماهيت ييجيده اين مؤلفه برمى كردد؛ جر اكه

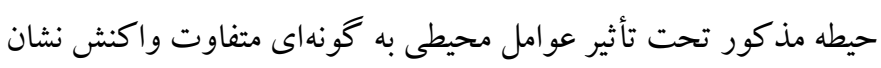

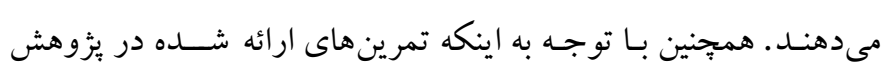

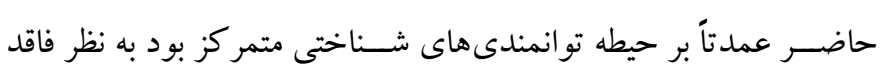
قدرت كافى براى ايجاد تغيير معنادار در اين مؤلفه هستند.

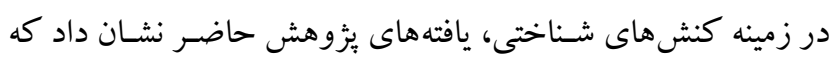

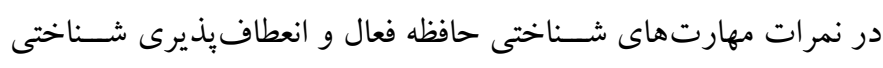

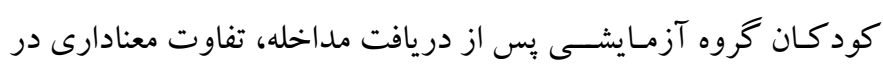

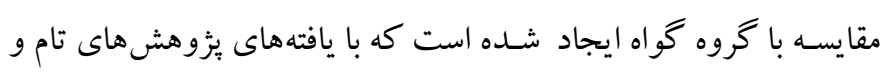

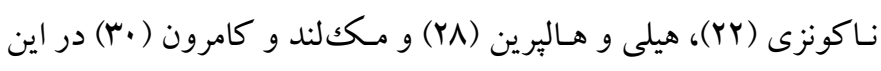

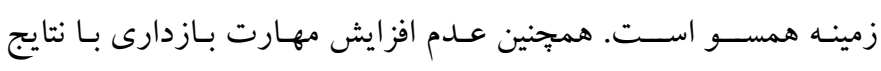

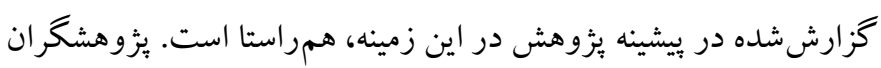

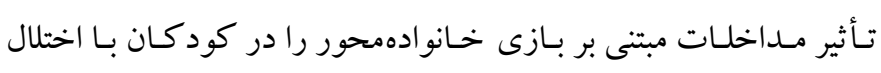

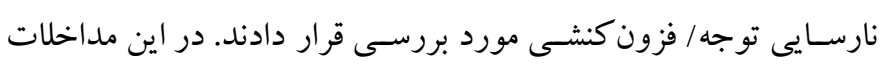

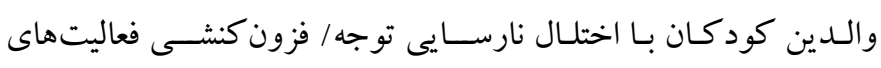

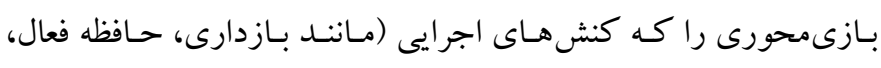

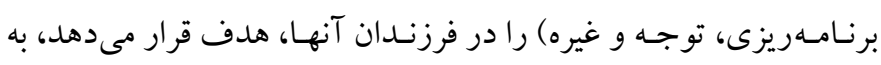

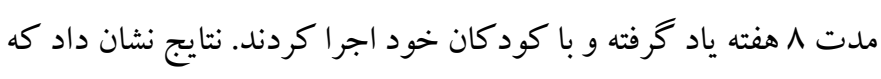

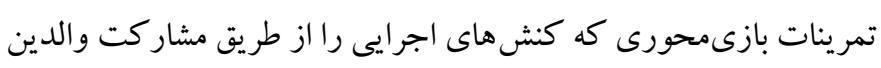

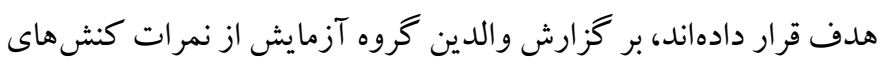

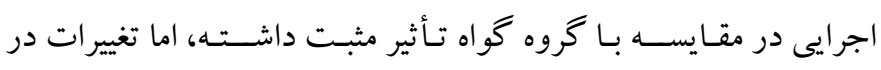

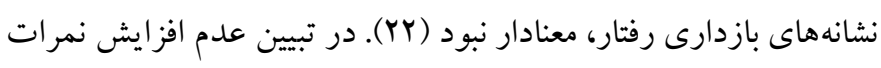
بازدارى رفتار، بررسسى يزوهش هاى انجام شـــه در دو دهه اخير نشـان

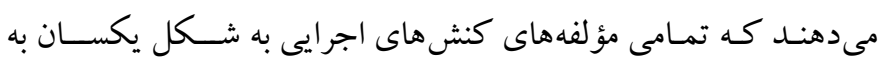

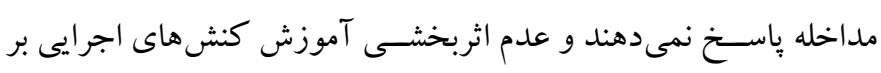

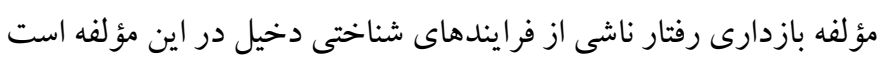

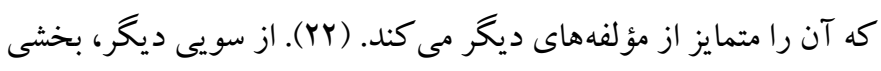

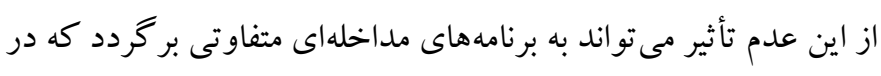
يُزو هش هاى مختلف استفاده شده است. همجِنين لازم به ذكر است كه در

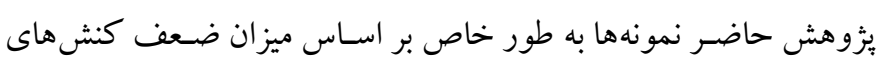

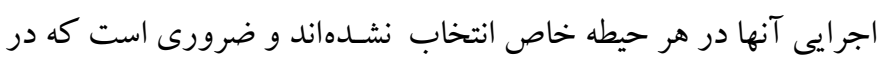

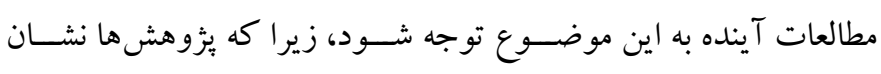




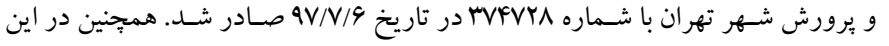

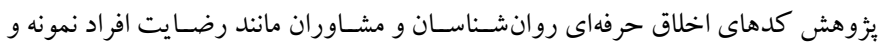
والدين آنان كاملاً رعايت شده است. حامى مالى: اين مطالعه به طور مستقل و بدون حامى مالى انجام شده است.

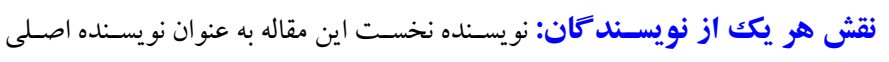

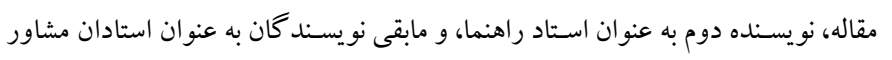

$$
\text { نقش داشتند. }
$$

تضاد منافع: اين يُوهش براى نويسند كان هيج گونه تضاد منافع به دنبال نداشته است.

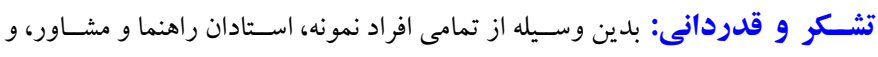

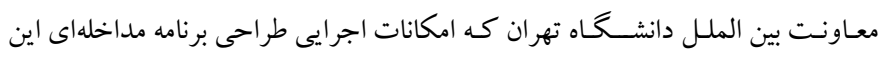

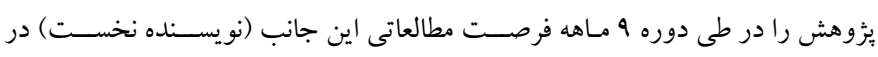

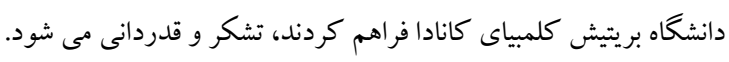

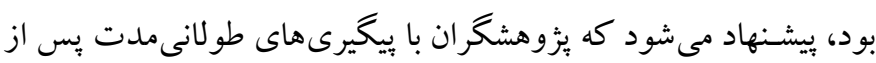

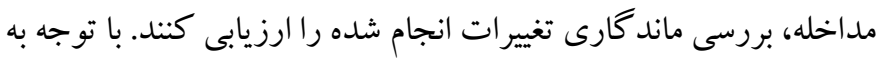

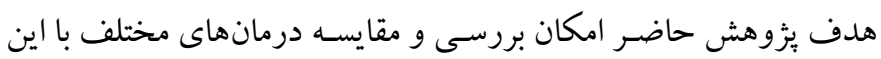

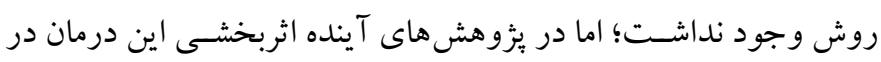

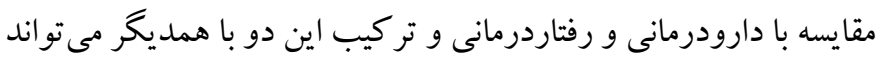
اثربخشى انفرادى و تعاملى هر يكك را بررسى كند.

ملاحظات اخلاقى بيروى از اصول اخلاق بثوهش: اين ئزوهش مربوط به رساله دكتراى خانم نخين

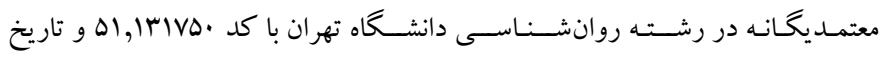

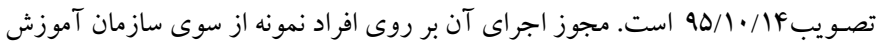




\section{References}

1. Evans SW, Langberg JM, Schultz BK, Vaughn A, Altaye M, Marshall SA, Zoromski AK. Evaluation of a school-based treatment program for young adolescents with ADHD. Journal of Consulting and Clinical Psychology. 2016; 84(1): 15. [Link]

2. American Psychiatric Association. Diagnostic and statistical manual of mental disorders (DSM-5®). American Psychiatric Pub; 2013. [Link]

3. Cortese S, Holtmann M, Banaschewski T, Buitelaar J, Coghill D, Danckaerts M, Dittmann RW, Graham J, Taylor E, Sergeant J, European ADHD Guidelines Group. Practitioner review: current best practice in the management of adverse events during treatment with ADHD medications in children and adolescents. Journal of Child Psychology and Psychiatry. 2013; 54(3): 227-46. [Link]

4. Chacko A, Kofler M, Jarrett M. Improving outcomes for youth with ADHD: A conceptual framework for combined neurocognitive and skill-based treatment approaches. Clinical Child and Family Psychology Review. 2014; 17(4): 368-384. [Link]

5. Meltzer L, editor. Executive function in education: From theory to practice. Guilford Publications; 2018. [Link]

6. Dajani DR, Llabre MM, Nebel MB, Mostofsky SH, Uddin LQ. Heterogeneity of executive functions among comorbid neurodevelopmental disorders. Scientific Reports. 2016; 6: 36566. [Link]

7. Diamond A. Executive functions. Annual review of psychology. 2013; 64: 135-168. [Link]

8. Krieger V, Amador-Campos JA. Assessment of executive function in ADHD adolescents: contribution of performance tests and rating scales. Child Neuropsychology. 2018; 24(8) :1063-1087. [Link]

9. Diamond A. Activities and programs that improve children's executive functions. Current directions in psychological science. 2012; 21(5): 335-341. [Link]

10. Shuai L, Daley D, Wang YF, Zhang JS, Kong YT, Tan $\mathrm{X}, \mathrm{Ji}$ N. Executive function training for children with attention deficit hyperactivity disorder. Chinese medical journal. 2017; 130(5): 549. [Link]

11.Bul KC, Kato PM, Van der Oord S, Danckaerts M, Vreeke LJ, Willems A, Van Oers HJ, Van Den Heuvel R, Birnie D, Van Amelsvoort TA, Franken IH. Behavioral outcome effects of serious gaming as an adjunct to treatment for children with attentiondeficit/hyperactivity disorder: a randomized controlled trial. Journal of medical Internet research. 2016; 18(2). [Link]

12.Hassan Nattaj F, Taghipour javan A, Faramarzi S, Rastgar $\mathrm{F}$.The Impact of Cognitive-Based Video Games on Executive Functions in Preschool Children with Neuropsychological Learning Disabilities. Quarterly Journal of Child Psychological Development. 2015; 2(2): 35-45. [Persian] [Link]

13.Jacob R, Parkinson J. The potential for school-based interventions that target executive function to improve academic achievement: A review. Review of Educational Research. 2015; 85(4): 512-552. [Link]

14. Thorell LB, Lindqvist S, Bergman Nutley S, Bohlin G, Klingberg T. Training and transfer effects of executive functions in preschool children. Developmental science. 2009; 12(1):106-13. [Link]

15.Bikic A, Leckman JF, Christensen TØ, Bilenberg N, Dalsgaard S. Attention and executive functions computer training for attention-deficit/hyperactivity disorder (ADHD): results from a randomized, controlled trial. European child \& adolescent psychiatry. 2018; 11: 1-2. [Link]

16. Re AM, Capodieci A, Cornoldi C. Effect of training focused on executive functions (attention, inhibition, and working memory) in preschoolers exhibiting ADHD symptoms. Frontiers in psychology. 2015; 6: 1161. [Link]

17.Hahn-Markowitz J, Berger I, Manor I, Maeir A. Efficacy of cognitive-functional (Cog-Fun) occupational therapy intervention among children with ADHD: An RCT. Journal of attention disorders. 2016; 24(5): 655-666. [Link]

18.Pisacco NM, Sperafico YL, Enricone JR, Guimarães LS, Rohde LA, Dorneles BV. Metacognitive interventions in text production and working memory in students with ADHD. Psicologia: Reflexão e Crítica. 2018; 31(1): 5. [Link]

19.Pezzica S, Vezzani C, Pinto G. Metacognitive knowledge of attention in children with and without ADHD symptoms. Research in developmental disabilities. 2018; 83: 142-52. [Link]

20.Vuori M, Tuulio-Henriksson A, Nissinen H, AuttiRämö I. Family-based psychosocial interventions for children with attention deficit hyperactivity disorder (ADHD), oppositional defiant disorder, and conduct disorder. Duodecim; laaketieteellinen aikakauskirja. 2015; 131(17): 1561-8. [Link]

21.Tamm L, Nakonezny PA, Hughes CW. An open trial of a metacognitive executive function training for young children with ADHD. Journal of Attention Disorders. 2014; 18(6): 551-559. [Link] 
22.Tamm L, Nakonezny PA. Metacognitive executive function training for young children with ADHD: A proof-of-concept study. ADHD Attention Deficit and Hyperactivity Disorders. 2015; 7(3): 183-190. [Link]

23. Shiri Aminloo M, Kamkary K, Shokrzadeh S. The concurrent validity of the new version of the TehranStanford-Binet Intelligence Scale with the Wechsler Intelligence Scale for Children-Revised. Exceptional education. 2013; 7: 50-61. [Persian] [Link]

24.Afrooz G A, Farid F, Mousavi MR, Soveyzi R. Construct validity assessment: Convergent type for Stanford Binet and Wechsler Intelligence Scale for children in Tehran. Annual Research \& Review in Biology. 2014; 4(24): 4400-4412. [Persian] [Link]

25. Wigal SB, Gupta S. Reliability and validity of the SKAMP Rating Scale ln a Laboratory School Setting. [Link]

26. Sadrolsadat J, Hoshyari Z, Zamani R, Sadrolsadat L. The psychometric characteristics of SNAP-IV rating scale, parent form. Rehabilitation. 2007; 8(3): 59-65. [Persian] [Link]
27.Gualtieri CT, Johnson LG. Reliability and validity of a computerized neurocognitive test battery, CNS Vital Signs. Archives of Clinical Neuropsychology. 2006; 21(7): 623-643. [Link]

28. Healey DM, Halperin JM. Enhancing Neurobehavioral Gains with the Aid of Games and Exercise (ENGAGE): Initial open trial of a novel early intervention fostering the development of preschoolers' self-regulation. Child Neuropsychology. 2015; 21(4): 465-480. [Link]

29. O’Neill S, Rajendran K, Halperin JM. More than child's play: the potential benefits of play-based interventions for young children with ADHD. Expert review of neurotherapeutics. 2012; 12(10): 11651167. [Link]

30.McClelland MM, Cameron CE. Self-regulation in early childhood: Improving conceptual clarity and developing ecologically valid measures. Child development perspectives. 2012; 6(2): 136-42. [Link] 